\title{
A Functional [NiFe]-Hydrogenase Model Compound That Undergoes Biologically Relevant Reversible Thiolate Protonation
}

\author{
Katharina Weber, Tobias Krämer, Hannah S. Shafaat, Thomas Weyhermüller, Eckhard Bill, \\ Maurice van Gastel, Frank Neese, and Wolfgang Lubitz* \\ Max Planck Institute for Chemical Energy Conversion, Stiftstrasse 34-36, D-45470 Mülheim an der Ruhr, Germany
}

\section{Supporting Information}

ABSTRACT: Two model compounds of the active site of $[\mathrm{NiFe}]$-hydrogenases with an unusual $\left\{\mathrm{S}_{2} \mathrm{Ni}(\mu\right.$-S $)(\mu$-CO $) \mathrm{Fe}-$ $\left.(\mathrm{CO})_{2} \mathrm{~S}\right\}$-coordination environment around the metals are reported. The neutral compound $[\mathrm{Ni}(\mathrm{xbsms})(\mu$-CO $)(\mu-\mathrm{S}) \mathrm{Fe}-$ $\left.(\mathrm{CO})_{2}\left({ }^{\prime} \mathrm{S} '\right)\right]$, (1) $\left(\mathrm{H}_{2} \mathrm{xbsms}=1,2\right.$-bis (4-mercapto-3,3-dimethyl-2-thiabutyl)benzene) is converted to $[1 \mathrm{H}]\left[\mathrm{BF}_{4}\right]$ by reversible protonation using $\mathrm{HBF}_{4} \cdot \mathrm{Et}_{2} \mathrm{O}$. The protonation takes place at the terminal thiolate sulfur atom that is coordinated to nickel. Catalytic intermediates with a
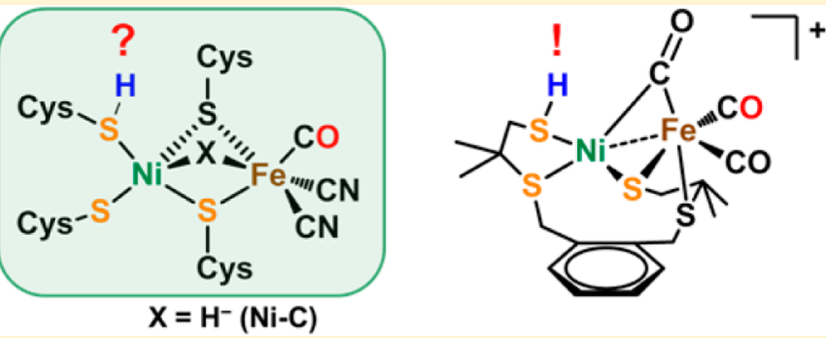
protonated terminal cysteinate were suggested for the native protein but have not yet been confirmed experimentally. $[1 \mathrm{H}]\left[\mathrm{BF}_{4}\right]$ is the first dinuclear $[\mathrm{NiFe}]$ model compound for such a species. Both complexes have been synthesized and characterized by X-ray crystallography, NMR-, FTIR-, and ${ }^{57}$ Fe-Mössbauer spectroscopy as well as by electronic absorption and resonance Raman spectroscopy. The experimental results clearly show that the protonation has a significant impact on the electronic structure of the iron center, although it takes place at the nickel site. DFT calculations support the interpretation of the spectroscopic data and indicate the presence of a bonding interaction between the metal ions, which is relevant for the enzyme as well. Electrochemical experiments show that both 1 and $[1 \mathrm{H}]\left[\mathrm{BF}_{4}\right]$ are active for electrocatalytic proton reduction in aprotic solvents.

\section{INTRODUCTION}

Hydrogen is considered the ideal fuel of the future since its combustion generates only water. However, in order to make a hydrogen economy viable, new hydrogen-processing catalysts are needed to replace the highly efficient but expensive platinum. ${ }^{1,2}$ One promising alternative is to use biomimetic models of hydrogenases, a class of metalloenzymes that function in Nature to catalyze the conversion of hydrogen to protons and electrons and vice versa. ${ }^{3}[\mathrm{NiFe}]$-hydrogenases are the most abundant of the three major classes, namely, the $[\mathrm{NiFe}],[\mathrm{FeFe}]$, and $[\mathrm{Fe}]$-hydrogenases, which are classified by their active sites. ${ }^{4}$

Since the elucidation of the enzyme structure, [NiFe]hydrogenases have been investigated extensively in order to better understand the catalytic mechanism. ${ }^{5-8}$ The active site contains a heterobimetallic $[\mathrm{NiFe}]$-complex. The oxidation state of the nickel atom changes while the iron atom is assumed to remain low-spin $\mathrm{Fe}$ (II) throughout the catalytic cycle. The nickel atom is ligated by four cysteine residues, two of which are coordinated terminally; the other two are bridging between nickel and the $\left\{\mathrm{Fe}(\mathrm{CN})_{2}(\mathrm{CO})\right\}$-moiety (see box in Scheme 1).

In parallel to the spectroscopic, electrochemical, and structural investigations of the enzyme, the design and synthesis of model compounds that mimic the active site has been a challenging task for bioinorganic chemists. ${ }^{9-12}$ Some structural models emulate the asymmetric active site of the enzyme remarkably well. ${ }^{13-16}$ Most of the other previously reported dinuclear models reproduce certain structural features of the active site and contain amine-thiolate ligands, phosphines or nitric oxide at the $\mathrm{Ni}$ or Fe site. ${ }^{17-25}$ So far, only a few dinuclear $[\mathrm{NiFe}]$-compounds have been reported with electrocatalytic activity toward proton reduction. ${ }^{26-28}$ Recently, Rauchfuss et al. reported on the protonation of a $\mathrm{Ni}(\mathrm{I})-\mathrm{Fe}(\mathrm{I})$ compound yielding a stable bridging hydride which was shown to be an intermediate in the electrocatalytic hydrogen evolution from trifluoroacetic acid $\left(\mathrm{CF}_{3} \mathrm{CO}_{2} \mathrm{H}\right)$ in dichloromethane (Scheme $\mathrm{S} 1$ in the Supporting Information). ${ }^{26,27}$ This model compound contains a $\mu$-hydrido species, which is also present as an intermediate in the catalytic cycle of the native system, as shown by spectroscopy and by DFT calculations. ${ }^{29-35}$ Catalytic intermediates with a protonated terminal cysteinate were also suggested theoretically. ${ }^{29,36-38}$ The catalytically active form $\mathrm{Ni}-\mathrm{C}$ of the enzyme was suggested to exist as $\left[\left(\mathrm{S}_{\text {cys }}-\right.\right.$ $\left.\mathrm{H})\left(\mathrm{S}_{\text {cys }}\right) \mathrm{Ni}(\mathrm{III})(\mu-\mathrm{H})\left(\mu-\mathrm{S}_{\mathrm{cys}}\right)_{2} \mathrm{Fe}(\mathrm{CO})(\mathrm{CN})_{2}\right]$ with a $\mathrm{S}_{\text {cys }}-\mathrm{H}$ proton. ${ }^{36,38}$ Also for the EPR-silent $\mathrm{Ni}-\mathrm{SIa}$ and $\mathrm{Ni}-\mathrm{R}$ states, the presence of a terminal $S_{\text {cys }}-\mathrm{H}$ proton was proposed by Hall and De Gioia. ${ }^{29,36}$ However, it is challenging to stabilize and characterize such intermediates in the protein pocket, and therefore, only indirect experimental evidence for the proposed $\mathrm{Cys}-\mathrm{SH}$ proton has been reported so far. For the Ni-SIa state, two isoelectronic species at different $\mathrm{pH}$-values within the $\mathrm{p} K_{\mathrm{a}}$

Received: October 2, 2012

Published: November 29, 2012 
range of cysteine thiol groups have been reported, suggesting that one of the cysteinate residues of the active site might be protonated. ${ }^{39}$ Furthermore, a crystallographic study of the COinhibited form of the $[\mathrm{NiFe}]$-hydrogenase isolated from Desulfovibrio vulgaris Miyazaki F indicates a possible protonation of the terminal Cys 546 residue due to the high temperature factor observed for this sulfur atom compared to the other three sulfur atoms in the active site. ${ }^{40}$

To model the nickel site of the protonated species, Liaw et al. synthesized and characterized mononuclear Ni-compounds containing an intramolecular $\mathrm{SH}$ proton. ${ }^{41-44}$ Henderson et al. studied the mechanism of the protonation of thiolate ligands bound to $\{\mathrm{Ni}(\text { tertiary phosphine })\}^{2+}$ using stopped-flow spectrophotometry. ${ }^{45-47}$ To the best of our knowledge, dinuclear $[\mathrm{NiFe}]$-compounds of this type have not been described so far.

In this work, we report the synthesis and characterization of a dinuclear $[\mathrm{NiFe}]$-model compound with the unusual $\left\{\mathrm{S}_{2} \mathrm{Ni}(\mu\right.$ $\mathrm{S})(\mu$-CO $\left.) \mathrm{Fe}(\mathrm{CO})_{2} \mathrm{~S}\right\}$-coordination environment. Reversible protonation of this compound occurs at the terminal sulfur atom coordinated to nickel, giving rise to the first $[\mathrm{NiFe}]$ model compound for this proposed intermediate in the natural catalytic cycle of $[\mathrm{NiFe}]$-hydrogenases. The protonation implicates a significant change of the electronic structure which is observed spectroscopically and supported by DFTcalculations. The electronic communication between the metal atoms occurs through the metal-metal bond, which is also discussed for the active site of the $[\mathrm{NiFe}]$-hydrogenases. ${ }^{48}$ Furthermore, both the unprotonated and protonated model compounds are functional and reveal electrocatalytic activity toward proton reduction in aprotic solvents.

\section{RESULTS}

Synthesis. Reaction of $[\mathrm{Ni}(\mathrm{xbsms})]\left(\mathrm{H}_{2} \mathrm{xbsms}=1,2-\mathrm{bis}(4-\right.$ mercapto-3,3-dimethyl-2-thiabutyl)benzene) with $[\mathrm{Fe}-$ $\left.(\mathrm{CO})_{3}(\mathrm{BDA})\right]$ (BDA = benzylidene acetone $)$ in dichloromethane under inert atmosphere at room temperature yields compound 1 (Scheme 1). ${ }^{49,50}$ After purification via column chromatography on silica gel, $\mathbf{1}$ can be isolated as a red solid,

Scheme 1. Synthesis of 1 and $[1 \mathrm{H}][\mathrm{BF} 4]^{a}$

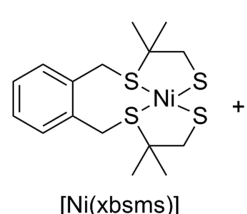

[Ni(xbsms)]
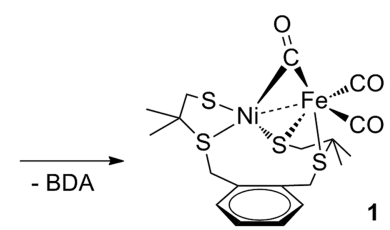

$\mathrm{HBF}_{4} \cdot \mathrm{Et}_{2} \mathrm{O}$

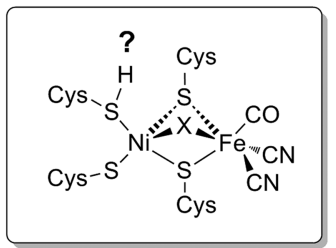

which is soluble in $\mathrm{CH}_{2} \mathrm{Cl}_{2}, \mathrm{THF}$, and acetonitrile without decomposition. It is stable in water but insoluble in this solvent.

Treatment of a dichloromethane solution of 1 with 1 equiv of $\mathrm{HBF}_{4} \cdot \mathrm{Et}_{2} \mathrm{O}$ at room temperature results in immediate color change from red to the brown solution of the respective protonated compound $[1 \mathrm{H}]^{+}$. The tetrafluoroborate salt $[1 \mathrm{H}]\left[\mathrm{BF}_{4}\right]$ was isolated in quantitative yield as a brown microcrystalline solid, which is soluble in $\mathrm{CH}_{2} \mathrm{Cl}_{2}, \mathrm{THF}$, and acetonitrile. It is deprotonated by addition of water to restore 1.

Structural Characterization. Single-crystal X-ray structure determinations have been performed for both $1 \cdot 0.5 \mathrm{Et}_{2} \mathrm{O}$ and $[1 \mathrm{H}]\left[\mathrm{BF}_{4}\right] \cdot 0.5$ 1,2-difluorobenzene. The molecular structures are given in Figure 1 and selected bond distances and angles are listed in Table 1 .

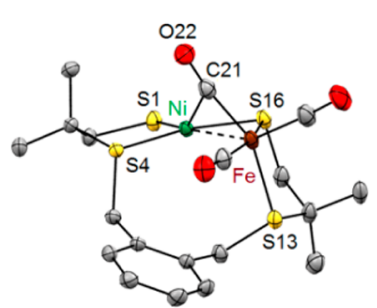

a)

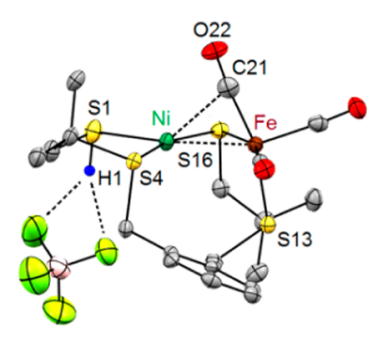

b)
Figure 1. Molecular structures of (a) compound 1 and $(b)[1 \mathrm{H}]\left[\mathrm{BF}_{4}\right]$. Thermal ellipsoids are shown at the 50\% probability level. Hydrogen atoms and most carbon labels are omitted for clarity.

Table 1. Selected Bond Distances and Angles in 1 and $[\mathbf{1 H}]\left[\mathrm{BF}_{4}\right]$

\begin{tabular}{lll} 
distances $[\AA]$ & \multicolumn{1}{c}{$\mathbf{1}$} & {$[1 \mathrm{H}]\left[\mathrm{BF}_{4}\right]$} \\
$\mathrm{Ni}-\mathrm{Fe}$ & $2.4262(2)$ & $2.4332(8)$ \\
$\mathrm{Ni}-\mathrm{S} 1$ & $2.1644(3)$ & $2.2276(11)$ \\
$\mathrm{Ni}-\mathrm{S} 16$ & $2.1749(3)$ & $2.1545(10)$ \\
$\mathrm{Ni}-\mathrm{S} 4$ & $2.1942(3)$ & $2.1899(10)$ \\
$\mathrm{Fe}-\mathrm{S} 16$ & $2.2567(3)$ & $2.2376(10)$ \\
$\mathrm{Fe}-\mathrm{S} 13$ & $2.3058(4)$ & $2.2883(10)$ \\
$\mathrm{Ni}-\mathrm{C} 21$ & $2.0348(11)$ & $2.407(4)$ \\
$\mathrm{Fe}-\mathrm{C} 21$ & $1.8231(12)$ & $1.790(4)$ \\
$\mathrm{C} 21-\mathrm{O} 22$ & $1.1654(14)$ & $1.146(5)$ \\
$\mathrm{S} 1-\mathrm{H} 1$ & - & $1.25(4)$ \\
angles $[\mathrm{deg}]$ & \multicolumn{1}{c}{1} & {$[1 \mathrm{H}]\left[\mathrm{BF} \mathrm{F}_{4}\right]$} \\
$\mathrm{S} 1-\mathrm{Ni}-\mathrm{S}(16)$ & $99.201(11)$ & $104.60(4)$ \\
$\mathrm{S} 1-\mathrm{Ni}-\mathrm{S}(4)$ & $93.971(12)$ & $93.38(4)$ \\
$\mathrm{S} 1-\mathrm{Ni}-\mathrm{Fe}$ & $157.010(10)$ & 162.5 \\
$\mathrm{Ni}-\mathrm{S} 16-\mathrm{Fe}$ & $66.360(9)$ & $67.25(3)$ \\
$\mathrm{O} 22-\mathrm{C} 21-\mathrm{Fe}$ & $161.97(9)$ & $173.8(4)$ \\
\hline
\end{tabular}

In contrast to the $\left[\mathrm{Ni}(\mathrm{xbsms}) \mathrm{Fe}\left(\mathrm{CO}_{4}\right)\right]$ complex which was reported by Bouwman et al., ${ }^{22}$ the reaction of $[\mathrm{Ni}(\mathrm{xbsms})]$ with $\left[\mathrm{Fe}(\mathrm{CO})_{3}(\mathrm{BDA})\right]$ yields the dinuclear $[\mathrm{NiFe}]$-compound $\mathbf{1}$ with the unexpected $\left\{\mathrm{S}_{2} \mathrm{Ni}(\mu-\mathrm{S})(\mu\right.$-CO $\left.) \mathrm{Fe}(\mathrm{CO})_{2} \mathrm{~S}\right\}$-core which differs from the active site of the $[\mathrm{NiFe}]$-hydrogenase in some features. The $\mathrm{NiS}_{4}$ unit of the starting compound $[\mathrm{Ni}(\mathrm{xbsms})]$, formed by the four sulfur atoms of the thioether and thiolate functions of the chelating $\mathrm{xbsms}^{2-}$ ligand, is no longer intact in 1 or $[1 \mathrm{H}]\left[\mathrm{BF}_{4}\right]$. Only three of the four sulfur atoms remain coordinated to nickel and one of the thioether sulfur atoms, $S 13$, is coordinated terminally to iron. One thiolate sulfur atom, $\mathrm{S} 16$, is in a bridging position between the metal ions and the
${ }^{a}$ Box: structure of the active site of the standard [NiFe]-hydrogenase in the oxidized inactive ready state $\left(\mathrm{Ni}-\mathrm{B}, \mathrm{X}=\mathrm{OH}^{-}\right)^{51}$ or reduced $\mathrm{Ni}-\mathrm{C}$ active state $\left(\mathrm{X}=\mathrm{H}^{-}\right)$. 
other, $\mathrm{S} 1$, is coordinated terminally to nickel. Both compounds reveal a short metal-metal distance of $2.43 \AA$.

The coordination geometry at iron is quasi-trigonal bipyramidal with two terminal and one bridging $\mathrm{CO}$ ligands as well as one terminal and one bridging sulfur atom. The nickel atom adopts a strongly distorted tetrahedral geometry and is coordinated by three sulfur atoms and the bridging $\mathrm{CO}$. The $\{\mathrm{Ni}(\mu$-CO $)(\mu-\mathrm{S}) \mathrm{Fe}\}$-core is $\mathrm{V}$-shaped and the dihedral angle, defined by the $\mathrm{Ni}-\mathrm{C} 21-\mathrm{Fe}$ and the $\mathrm{Ni}-\mathrm{S} 16-\mathrm{Fe}$ planes, changes upon protonation from $69.7^{\circ}$ in 1 to $77.8^{\circ}$ in $[1 \mathrm{H}]\left[\mathrm{BF}_{4}\right]$. The $\mathrm{CO}$ ligand between the metals becomes less bridging after protonation: the $\mathrm{Fe}-\mathrm{C} 21-\mathrm{O} 22$ angle changes from $162.0^{\circ}$ in 1 to $173.8^{\circ}$ in $[1 \mathrm{H}]\left[\mathrm{BF}_{4}\right]$. The position of the proton $\mathrm{H} 1$ at the terminal sulfur $\mathrm{S} 1$ in $[1 \mathrm{H}]\left[\mathrm{BF}_{4}\right]$ was identified from the difference map of electron density, for which isotropic refinement was allowed. Furthermore, of all the $\mathrm{Ni}-\mathrm{S}$ distances, the $\mathrm{Ni}-\mathrm{S} 1$ bond length changes most significantly in the protonated compound which is also indicative of protonation at $\mathrm{S} 1$. The counteranion $\left[\mathrm{BF}_{4}\right]^{-}$is oriented toward $\mathrm{H} 1$ owing to the formation of hydrogen bond interactions.

Spectroscopic Characterization. Changes upon Protonation Detected by FTIR-Spectroscopy. The infrared spectrum of compound $\mathbf{1}$ in dichloromethane displays three COstretching absorption bands in the carbonyl region at 2012, 1954, and $1854 \mathrm{~cm}^{-1}$ (Figure S1, Supporting Information). With the aid of DFT calculations, vibrations can be assigned to the symmetric $\left(2012 \mathrm{~cm}^{-1}\right)$ and the antisymmetric (1954 $\mathrm{cm}^{-1}$ ) stretching frequency of the terminal CO ligands and the stretching frequency of the bridging $\mathrm{CO}\left(1854 \mathrm{~cm}^{-1}\right)$, respectively. The corresponding $\mathrm{CO}$ bands observed for $[1 \mathrm{H}]\left[\mathrm{BF}_{4}\right]$ are shifted significantly to $2034 \mathrm{~cm}^{-1}\left(+22 \mathrm{~cm}^{-1}\right)$, $1982 \mathrm{~cm}^{-1}\left(+28 \mathrm{~cm}^{-1}\right)$, and $1932 \mathrm{~cm}^{-1}\left(+78 \mathrm{~cm}^{-1}\right)$ (Table 2).

Table 2. Calculated (RI-BP86/ZORA/def2-TZVP) and Experimental IR Frequencies for Complexes 1 and $[1 \mathrm{H}]^{+}$

\begin{tabular}{lrrrrr} 
& \multicolumn{2}{c}{$\mathbf{1} \tilde{v}\left[\mathrm{~cm}^{-1}\right]$} & & & {$[\mathbf{1 H}]^{+}, \tilde{v}\left[\mathrm{~cm}^{-1}\right]$} \\
\cline { 2 - 3 } \cline { 5 - 6 } mode & calc. & exp. & & calc. & exp. \\
CO (sym.) & 1995 & 2012 & & 2040 & 2034 \\
CO (asym.) & 1949 & 1954 & & 1999 & 1982 \\
CO (bridge) & 1850 & 1854 & & 1939 & 1932 \\
SH & - & - & & 2550 & 2512 \\
\hline
\end{tabular}

The increase of the stretching frequency corresponding to the bridging $\mathrm{CO}$ ligand and concomitant shortening of the C21$\mathrm{O} 22$ bond is in line with the observed large elongation of the $\mathrm{Ni}-\mathrm{C} 21$ bond in the molecular structure, where the bridging $\mathrm{CO}$ is mainly coordinated to Fe. The shift to higher wavenumbers in $[1 \mathrm{H}]\left[\mathrm{BF}_{4}\right]$ observed for the terminal $\mathrm{CO}$ ligands is due to the lower donor-ability of a thiol compared to a thiolate which leads to a decreased electron density at iron and thus less $\pi$-backdonation. De Lacey et al. reported two isoelectronic $\mathrm{Ni}-\mathrm{SIa}$ species in an acid-base-equilibrium in the $\mathrm{p} K_{\mathrm{a}}$ range of cysteinate thiol groups, thus, suggesting a protonation of the terminal cysteinate residue. ${ }^{39}$ The protonated Ni-SIa species displayed a shift of $+20 \mathrm{~cm}^{-1}$ for the observed $\mathrm{CO}$ frequency compared to the unprotonated form. However, other protonation sites could not be excluded. Our results are in good agreement with this study of the native system and support the suggestion made by de Lacey et al. that the terminal cysteinate is probably protonated.
Furthermore, in the FTIR spectrum ( $\mathrm{KBr}$ pellet) of $[1 \mathrm{H}]\left[\mathrm{BF}_{4}\right]$, an $\mathrm{S}-\mathrm{H}$ stretching band is observed in the typical region at $2512 \mathrm{~cm}^{-1}$ (Figure 2). The presence of the $\mathrm{S}-\mathrm{H}$

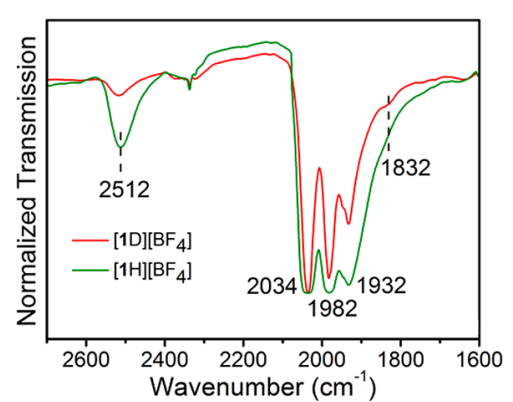

Figure 2. FTIR spectrum in the $\tilde{v}_{\mathrm{CO}}$ and the $\tilde{v}_{\mathrm{SH}}$ region of $\mathrm{KBr}$ pellets of $[1 \mathrm{H}]\left[\mathrm{BF}_{4}\right]$ and $[1 \mathrm{D}]\left[\mathrm{BF}_{4}\right]$.

stretching frequency is confirmed by deuterium exchange experiments (vide infra). The proton located on the terminal sulfur atom is acidic as $[1 \mathrm{H}]\left[\mathrm{BF}_{4}\right]$ is deprotonated by water and therefore exchangeable. The deuterated compound $[1 \mathrm{D}]\left[\mathrm{BF}_{4}\right]$ could be isolated as a microcrystalline solid after deuteration of the neutral compound 1 with $\mathrm{DBF}_{4} \cdot \mathrm{Et}_{2} \mathrm{O}$. In the FTIR spectrum ( $\mathrm{KBr}$ pellet), the signal of the $\mathrm{S}-\mathrm{H}$ stretching $\left(2512 \mathrm{~cm}^{-1}\right)$ decreases significantly and a new shoulder at 1832 $\mathrm{cm}^{-1}$ shows up (Figure 2). This shift to a lower wavenumber is due to the higher atomic mass of the deuteron compared to the proton. Assuming that the force constants do not differ significantly for the $\mathrm{S}-\mathrm{H}$ and the $\mathrm{S}-\mathrm{D}$ bonds, the vibration for S-D stretching is expected to be at $1809 \mathrm{~cm}^{-1}$. The observed band at $1832 \mathrm{~cm}^{-1}$ is in good agreement within this approximation.

Identification of the S-H Proton by NMR-Spectroscopy. The highly resolved NMR-spectra obtained for both 1 and $[1 \mathrm{H}]\left[\mathrm{BF}_{4}\right]$ clearly indicate that these formal $34 \mathrm{e}$-systems are diamagnetic. ${ }^{52}$ As the $x b_{s m s}{ }^{2-}$ ligand loses its high symmetry in both complexes, the protons of the methylene groups become diasterotopic and the geminal ${ }^{2} J_{\mathrm{H}-\mathrm{H}}$ couplings become observable in the ${ }^{1} \mathrm{H}$ NMR spectrum in $\mathrm{CD}_{2} \mathrm{Cl}_{2}$. The observed coupling constants of $10-12 \mathrm{~Hz}$ are in the typical range for geminal coupling of aliphatic protons. ${ }^{53}$ Using COSY-NMR, all resonance signals for both 1 and $[1 \mathrm{H}]\left[\mathrm{BF}_{4}\right]$ can be assigned (see Supporting Information). The ${ }^{13} \mathrm{C}$ NMR spectra also reflect the asymmetry of the $\mathrm{xbsms}^{2-}$ ligand as in both 1 and $[1 \mathrm{H}]\left[\mathrm{BF}_{4}\right]$, all carbon atoms appear to be inequivalent. However, only one weak $\mathrm{CO}$ signal is observed in the ${ }^{13} \mathrm{C}$ NMR spectra of both compounds which may be attributed to the exchangeability of the $\mathrm{CO}$ groups in solution. In the ${ }^{1} \mathrm{H}$ NMR spectrum of $[1 \mathrm{H}]\left[\mathrm{BF}_{4}\right]$, the signal of the thiol proton has been identified at $4.79 \mathrm{ppm}$. The ${ }^{1} \mathrm{H}$ NMR spectrum of the free $\mathrm{H}_{2} \mathrm{xbsms}$ ligand reveals a ${ }^{3} \mathrm{~J}_{\mathrm{H}-\mathrm{H}}$ coupling between the thiol and the methylene protons, ${ }^{49}$ whereas in the case of $[1 \mathrm{H}]\left[\mathrm{BF}_{4}\right]$, no coupling is observed for the thiol proton. This might be due to fast intermolecular exchange in solution.

A $\mathrm{CD}_{2} \mathrm{Cl}_{2}$-solution of $[1 \mathrm{H}]\left[\mathrm{BF}_{4}\right]$ was treated with $\mathrm{CD}_{3} \mathrm{CO}_{2} \mathrm{D}$ and the corresponding proton signal in the ${ }^{1} \mathrm{H}$ NMR spectrum disappeared after a few minutes. No decomposition was observed in the spectrum. The methylene region of ${ }^{1} \mathrm{H}$ NMR spectra of $1,[1 \mathrm{H}]\left[\mathrm{BF}_{4}\right]$, and $[1 \mathrm{D}]\left[\mathrm{BF}_{4}\right]$ are compared in Figure 3 and the signal of the acidic hydrogen atom is marked in the figure. 


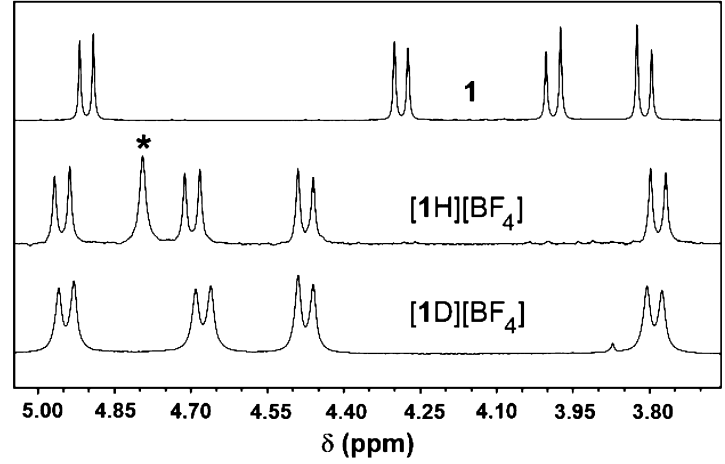

Figure 3. The methylene region of ${ }^{1} \mathrm{H}$ NMR spectra of $1,[1 \mathrm{H}]\left[\mathrm{BF}_{4}\right]$, and $[1 \mathrm{D}]\left[\mathrm{BF}_{4}\right]$. The signal of the $\mathrm{SH}$-proton is highlighted $(*)$. Full spectra are given in the Supporting Information.

Electronic Absorption Spectroscopy. Both compounds exhibit strong absorption bands in the visible region, as reflected by their apparent colors: $\mathbf{1}$ is red, while the protonated $[1 \mathrm{H}]\left[\mathrm{BF}_{4}\right]$ appears brown (Figure 4). The spectrum of 1 has

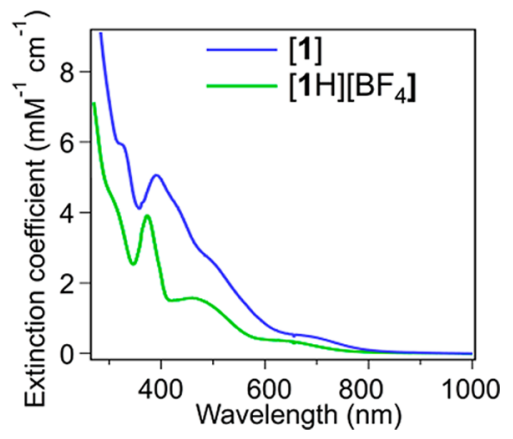

Figure 4. Absorption spectra of 1 and $[1 \mathrm{H}]\left[\mathrm{BF}_{4}\right]$ in dichloromethane.

broad bands extending through the visible range, while in $[1 \mathrm{H}]\left[\mathrm{BF}_{4}\right]$, those features collapse into sharper bands. The extinction coefficients of $\mathbf{1}$ are slightly higher than those observed for $[1 \mathrm{H}]\left[\mathrm{BF}_{4}\right]$, and all features are shifted to higher energies for $[1 \mathrm{H}]\left[\mathrm{BF}_{4}\right]$. These differences reflect the significant changes in the electronic structure of the metal core that occur upon protonation of the thiolate ligand.

Resonance Raman Spectroscopy. The resonance Raman (RR) spectra for $1,[1 \mathrm{H}]\left[\mathrm{BF}_{4}\right]$, and the isotope-substituted $[1 \mathrm{D}]\left[\mathrm{BF}_{4}\right]$ are shown in Figure 5. These spectra are dominated by high-intensity bands in the low-frequency region of the spectrum $\left(<650 \mathrm{~cm}^{-1}\right)$; these frequencies are typical for vibrations reflecting metal-ligand or metal-metal displacement. The enhancement of these modes suggests an electronic excitation that is dominantly metal-metal or metal-ligand based, which is consistent with TD-DFT calculations (see Supporting Information). Sharp bands are absent in the midfrequency region of the spectrum; only one small, broad band is seen for $[1 \mathrm{H}]\left[\mathrm{BF}_{4}\right]$ and $[1 \mathrm{D}]\left[\mathrm{BF}_{4}\right]$ around $950 \mathrm{~cm}^{-1}$ (Figure S9, Supporting Information). The high-frequency region of the spectrum reveals moderately intense vibrational bands from the carbonyl stretching modes. Two stretching modes for each compound are observed at the same frequencies as in the FTIR spectra. The third band, which is seen in the FTIR spectra at lower frequencies and attributed to the bridging $\mathrm{CO}$ ligand, is not observed in the RR spectra.

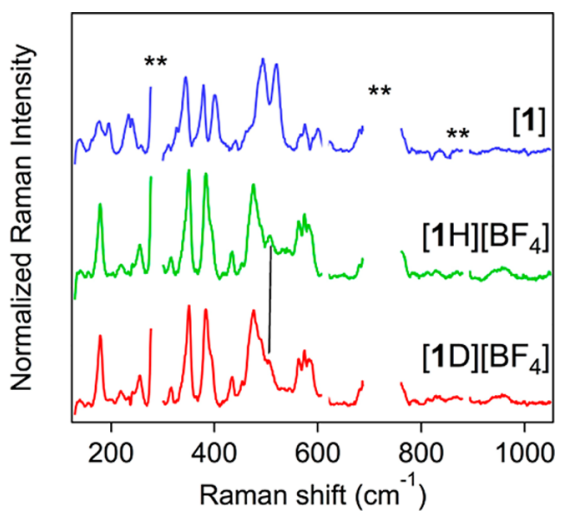

Figure 5. Resonance Raman (514 nm excitation, $77 \mathrm{~K}$ ) of 1, $[1 \mathrm{H}]\left[\mathrm{BF}_{4}\right]$, and $[1 \mathrm{D}]\left[\mathrm{BF}_{4}\right]$ in dichloromethane. Regions obscured by large solvent peaks have been removed for clarity and indicated with $(* *)$. Intensity for the high frequency region is multiplied by 1.5 for clarity. The shift at $508 \mathrm{~cm}^{-1}$ is indicated with the black line.

Resonance Raman spectra obtained for the deuterated compound are nearly identical to the spectra of $[1 \mathrm{H}]\left[\mathrm{BF}_{4}\right]$ (Figure 5). Only one obvious frequency shift occurs; the band at $508 \mathrm{~cm}^{-1}$ in $[1 \mathrm{H}]\left[\mathrm{BF}_{4}\right]$ is decreased by approximately 4 $\mathrm{cm}^{-1}$ in $[\mathrm{ID}]\left[\mathrm{BF}_{4}\right]$. The $\mathrm{SH}$-vibration is not observed in the RR spectra under these excitation conditions. This band is expected to be broad, ${ }^{54}$ and its absence may be due to interference from the solvent in that spectral region. Furthermore, if the electronic excitation is not delocalized onto these atoms, which would result in a change in bonding coordinate along the $\mathrm{S}-\mathrm{H}$ vibrational mode, this band will not undergo resonance enhancement upon excitation and therefore will remain invisible in the $\mathrm{RR}$ spectra.

${ }^{57} \mathrm{Fe}-$ Mössbauer Spectroscopy. Both compounds, 1 and $[1 \mathrm{H}]\left[\mathrm{BF}_{4}\right]$, were studied by Mössbauer spectroscopy. At $80 \mathrm{~K}$ and zero field, 1 exhibits a quadrupole doublet with low isomer shift and moderately large quadrupole splitting $(\delta=0.06 \mathrm{~mm} / \mathrm{s}$, $\Delta E_{\mathrm{Q}}=1.39 \mathrm{~mm} / \mathrm{s}$, Figure S7, Supporting Information). A Mössbauer spectrum recorded with an applied field of $4.0 \mathrm{~T}$ at $4.2 \mathrm{~K}$ shows only weak magnetic splitting from the applied field without a contribution from an internal field, which reveals the presence of a ground state with spin $S=0$ (Figure 6, left). A
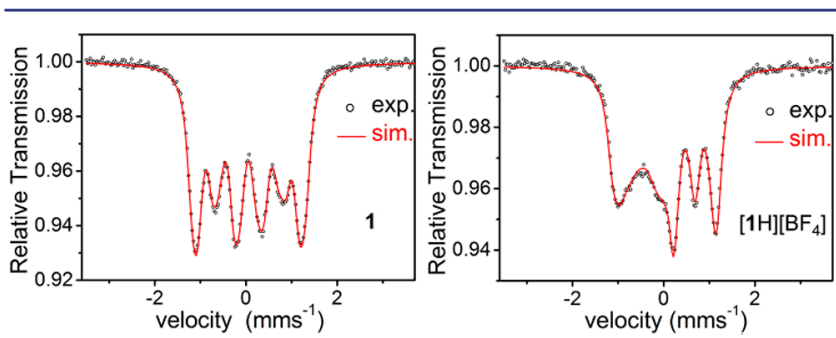

Figure 6. Mössbauer spectrum of 1 (left) and [1H][BF4] (right) recorded with an applied field of $4.0 \mathrm{~T}$ at $4.2 \mathrm{~K}$. The red line is a simulation for $S=0$ with the parameters given in Table 3 .

simulation yields a positive sign for the main component $V_{z z}$ of the electric field gradient (EFG), but the asymmetry parameter of the EFG was found to be large $(\eta=0.92)$, which means that the sign does not have much physical meaning. The Mössbauer parameters for $[1 \mathrm{H}]\left[\mathrm{BF}_{4}\right]$ determined under the same conditions are $\delta=0.05 \mathrm{~mm} / \mathrm{s}, \Delta E_{\mathrm{Q}}=-1.20 \mathrm{~mm} / \mathrm{s}, \eta=0.20$ (Figure 6, right and Figure S8). Here, the asymmetry parameter is remarkably small, and hence, the negative sign of $\Delta E_{Q}$ is 
significant. The small difference of the isomer shifts for both compounds $\left(0.06 \mathrm{~mm} / \mathrm{s}\right.$ in $1 \mathrm{vs} 0.05 \mathrm{~mm} / \mathrm{s}$ in $\left.[1 \mathrm{H}]\left[\mathrm{BF}_{4}\right]\right)$ is experimentally significant and reproducible, as two independent measurements of different samples of 1 and $[1 \mathrm{H}]\left[\mathrm{BF}_{4}\right]$ provided the same values. Theoretical parameters which were derived from DFT calculations are listed in Table 3 and are in excellent agreement with the experimental data. ${ }^{55}$

Table 3. Experimental and Calculated Mössbauer Parameters for 1 and $[1 \mathrm{H}]\left[\mathrm{BF}_{4}\right]$

\begin{tabular}{lcccc}
\multicolumn{1}{c}{ parameter } & 1, exp. & 1, calc. & {$[\mathrm{1H}][\mathrm{BF} 4]$, exp. } & {$[\mathrm{1H}][\mathrm{BF} 4]$, calc. } \\
$\delta,[\mathrm{mm} / \mathrm{s}]$ & 0.06 & 0.05 & 0.05 & 0.03 \\
$\Delta E_{\mathrm{Q}},[\mathrm{mm} / \mathrm{s}]$ & $1.39^{a}$ & $-1.37^{a}$ & -1.20 & -1.23 \\
$\eta$ & 0.92 & 0.92 & 0.20 & 0.18
\end{tabular}

${ }^{a}$ As in this case, the asymmetry parameter $\eta$ is close to 1 , the sign of the electric field gradient (defined by the sign of the main component $V_{z z}$ ) does not play a significant role.

Both, the diamagnetism $(S=0)$ and the unusual short $\mathrm{Ni}-\mathrm{Fe}$ distance of 1 and $[1 \mathrm{H}]\left[\mathrm{BF}_{4}\right]$ can be explained by the presence of a $\sigma$-bond between nickel and iron, as discussed in the DFT section (vide infra). Therefore, based on the total number of electrons, the metal ions are formally best described as $\mathrm{Ni}(\mathrm{I})$ and low-spin $\mathrm{Fe}(\mathrm{I})$. The low isomer shift observed for both complexes is suggestive of the postulated low-valence and lowspin state of the iron site, ${ }^{56}$ but the actual oxidation state cannot be corroborated because the key parameter, which is the Mössbauer isomer shift, does not properly correlate with the formal number of the valence electrons in this situation. The isomer shifts of 1 and $[1 \mathrm{H}]\left[\mathrm{BF}_{4}\right]$ are at the lower limit of the isomer shift range observed for [NiFe]-hydrogenases $(0.05-$ $0.15 \mathrm{~mm} / \mathrm{s}$ ) in which the iron has been described as low-spin $\mathrm{Fe}(\mathrm{II}){ }^{57}$ The Mössbauer isomer shifts of octahedral Fe(II) carbonyl complexes studied by Darensbourg et al. are in the range of $0.01-0.09 \mathrm{~mm} / \mathrm{s}^{58}$ The similarity of values for $\mathrm{Fe}(\mathrm{I})$ and $\mathrm{Fe}(\mathrm{II})$ with covalent ligands like $\mathrm{CO}$ arises from the strong $\pi$-backbonding observed for low-valent iron compounds, the changes of which compensate for the effect arising from the change in the number of valence $3 \mathrm{~d}$ electrons of the iron atom. We note in passing that the isomer shifts found for $\mathbf{1}$ and $[1 \mathrm{H}]\left[\mathrm{BF}_{4}\right]$ are consistent with the value $\delta=0.04 \mathrm{~mm} / \mathrm{s}$ determined for another synthetic $\mathrm{Ni}(\mathrm{I}) \mathrm{Fe}(\mathrm{I})$-compound [(dppe) $\left.\mathrm{Ni}(\mathrm{pdt}) \mathrm{Fe}(\mathrm{CO})_{3}\right]$ (2) (Scheme S1 in the Supporting Information), which also contains a $\mathrm{Ni}-\mathrm{Fe}$ bond and is therefore readily comparable to 1 and $[1 \mathrm{H}]\left[\mathrm{BF}_{4}\right]^{23,59}$

The difference of Mössbauer isomer shifts of $\mathbf{1}$ and $[1 \mathrm{H}]\left[\mathrm{BF}_{4}\right](0.06$ vs $0.05 \mathrm{~mm} / \mathrm{s})$ is interesting, considering the small range of observed isomer shifts for low-valent lowspin iron compounds in general, ${ }^{56}$ since it indicates that the protonation at the terminal sulfur coordinated to nickel in $[1 \mathrm{H}]\left[\mathrm{BF}_{4}\right]$ can be sensed by the electron density of the iron site. This can be explained by a change in the bridging mode of the $\mu$-CO ligand (C21 and O22 in Figure 1 ) in $[1 \mathrm{H}]\left[\mathrm{BF}_{4}\right]$ : the decrease of the bridging character, seen by the elongation of the $\mathrm{Ni}-\mathrm{C} 21$ bond and the shortening of the $\mathrm{Fe}-\mathrm{C} 21$ bond, increases the $\pi$-backdonation from iron to this CO ligand and thus decreases the isomer shift. Calculated isomer shifts reveal the same tendency though the values are underestimated in both cases (Table 3 ). ${ }^{55}$

The quadrupole splitting provides information about the local charge asymmetry of the iron site. For $\mathbf{1}$ its absolute value is significantly higher than for $[1 \mathrm{H}]\left[\mathrm{BF}_{4}\right]|1.39|$ vs $|1.20| \mathrm{mm} /$ s). The same trend is found also in the obtained asymmetry parameters $(\eta=0.92$ vs 0.20$)$. This is not surprising, since the iron atom in $\mathbf{1}$ appears to be embedded in a more asymmetric surrounding whereas through the adjustment of the electronic properties of all three $\mathrm{CO}$ ligands the iron environment in $[1 \mathrm{H}]\left[\mathrm{BF}_{4}\right]$ is less asymmetric. Such a significant change in the geometry is remarkable taking into account that the protonation itself does not involve the iron site directly. This observation underlines the electronic communication between the metals in these dinuclear complexes supported by the bridging $\mathrm{CO}$ ligand which participates in the bonding interaction between nickel and iron (see DFT calculations).

Electrochemical Characterization. Redox Properties of 1 and $[1 \mathrm{H}]\left[\mathrm{BF}_{4}\right]$. Cyclic voltammetry of 1 in $\mathrm{CH}_{2} \mathrm{Cl}_{2}$ at a scan rate of $500 \mathrm{mV} / \mathrm{s}$ indicates that the complex 1 undergoes a reversible reduction $\left(\Delta E_{\mathrm{p}}=160 \mathrm{mV}, i_{p a} / i_{p c} \approx 1\right)$ at $-1.75 \mathrm{~V}$ vs $\mathrm{Fc} / \mathrm{Fc}^{+}$(Figure S12, Supporting Information). The cathodic wave shows a less reversible character at smaller scan rates. The oxidation is completely irreversible $\left(E_{\mathrm{pa}}=0.21 \mathrm{~V} \mathrm{vs} \mathrm{Fc} / \mathrm{Fc}^{+}\right)$. In acetonitrile, the reduction is irreversible even at higher scan rates (up to $1600 \mathrm{mV} / \mathrm{s}$ ) at room temperature but appears at nearly the same potential $\left(E_{\mathrm{pc}}=-1.81 \mathrm{~V}\right.$ vs $\mathrm{Fc} / \mathrm{Fc}^{+}, i_{p a} / i_{p c} \leq$ 0.1 ). This might be due to different diffusion coefficients in these two solvents. At $-30{ }^{\circ} \mathrm{C}$, the reduction is reversible at a scan rate of $500 \mathrm{mV} / \mathrm{s}$.

The cyclic voltammogram of $[1 \mathrm{H}]\left[\mathrm{BF}_{4}\right]$ displays only irreversible redox behavior in both acetonitrile and dichloromethane $\left(E_{\mathrm{pc}}=-1.73 \mathrm{~V}\right.$ vs $\left.\mathrm{Fc} / \mathrm{Fc}^{+}\right)$even at the scan rate of $1600 \mathrm{mV} / \mathrm{s}$.

Electrocatalytic Evolution of Hydrogen in the Presence of $\mathrm{CF}_{3} \mathrm{CO}_{2} \mathrm{H}$. Effective electrocatalysts show enhanced current in cyclic voltammograms in the presence of acid nearly at the potential where the catalyst is reduced. ${ }^{60,61}$ Upon addition of increasing amounts of up to 100 equiv of $\mathrm{CF}_{3} \mathrm{CO}_{2} \mathrm{H}$ to acetonitrile or dichloromethane solutions of $\mathbf{1}$, cyclic voltammograms display increased cathodic current thus indicating electrocatalytic proton reduction (Figure 7).

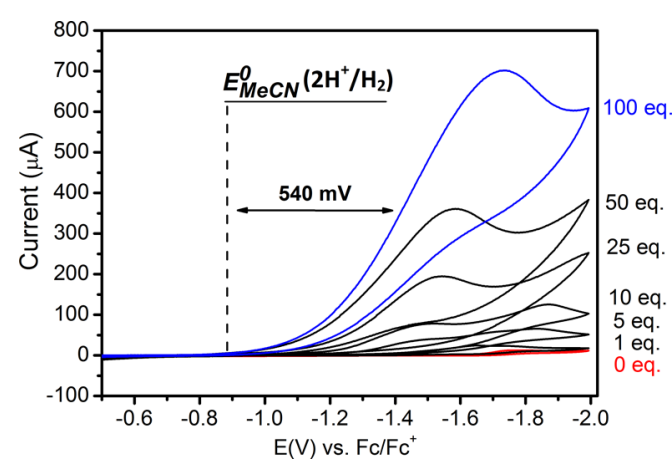

Figure 7. Cyclic voltammograms of 1 in $\mathrm{MeCN}\left(2 \mathrm{mmol} \mathrm{L}^{-1}\right)$ in the presence of various amounts of $\mathrm{CF}_{3} \mathrm{CO}_{2} \mathrm{H}$ recorded at glassy carbon working and counter electrodes $(d=2 \mathrm{~mm})$ and Ag-wire as a pseudoreference at a scan rate of $100 \mathrm{mV} / \mathrm{s}$ with $\mathrm{NBu}_{4} \mathrm{PF}_{6}(0.2 \mathrm{M})$ as the supporting electrolyte.

Since both the $\mathrm{p} K_{\mathrm{a}}$ and the standard redox potential are known for acetonitrile solutions of $\mathrm{CF}_{3} \mathrm{CO}_{2} \mathrm{H}\left(\mathrm{pK}_{\mathrm{a}}^{\mathrm{MeCN}}=\right.$ $12.65,{ }^{62} E^{0, \mathrm{MeCN}}\left(\mathrm{CF}_{3} \mathrm{CO}_{2} \mathrm{H} / \mathrm{H}_{2}\right)=-0.89 \mathrm{~V} \mathrm{vs} \mathrm{Fc} / \mathrm{Fc}^{+}$ calculated using Evans' relationship, ${ }^{60}$ homoconjugation not taken into account), and not dichloromethane, the interpretation of the cyclic voltammograms recorded in acetonitrile is more meaningful despite the irreversibility of the initial 
cathodic wave in this solvent. The reported overpotential of $540 \mathrm{mV}$ for the electrocatalytic proton reduction is estimated from the potential at $0.5\left(i_{\mathrm{pc}}\right)$, where $i_{\mathrm{pc}}$ is the cathodic peak current in the cyclic voltammogram recorded after addition of 100 equivalents of the acid (Figure 7). As was recently mentioned by Artero et al., this definition of the overpotential allows a more reliable comparison of different molecular catalysts. $^{61}$

A catalytic current is also observed under the same conditions using $[1 \mathrm{H}]\left[\mathrm{BF}_{4}\right]$ as the catalyst (Figure 8 ). The

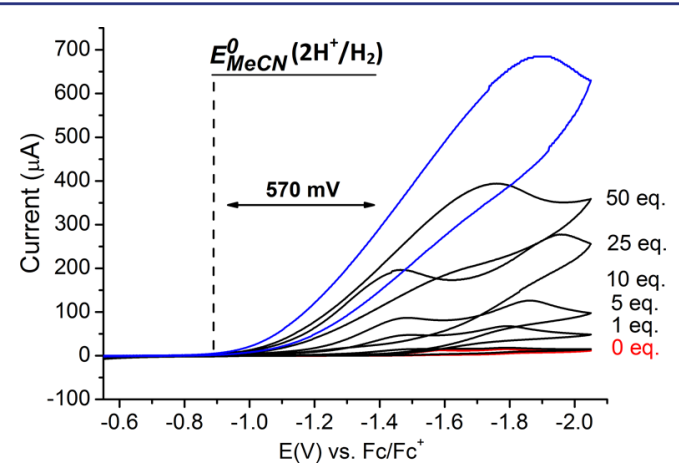

Figure 8. Cyclic voltammograms of $[1 \mathrm{H}]\left[\mathrm{BF}_{4}\right]$ in $\mathrm{MeCN}(2 \mathrm{mmol}$ $\left.\mathrm{L}^{-1}\right)$ in the presence of various amounts of $\mathrm{CF}_{3} \mathrm{CO}_{2} \mathrm{H}$ recorded at glassy carbon working and counter electrodes $(d=2 \mathrm{~mm})$ and Ag-wire as a pseudoreference at a scan rate of $100 \mathrm{mV} / \mathrm{s}$ with $\mathrm{NBu}_{4} \mathrm{PF}_{6}(0.2$ $\mathrm{M})$ as the supporting electrolyte.

catalytic peak current is observed at slightly lower potentials than for 1. An overpotential of $570 \mathrm{mV}$ is calculated as described above. However, we estimate that the errors of the overpotentials are $\pm 50 \mathrm{mV}$ which means that the difference of $30 \mathrm{mV}$ between 1 and $[1 \mathrm{H}]\left[\mathrm{BF}_{4}\right]$ is within the experimental error.

Bulk Electrolysis Experiments. To definitively assign the above electrocatalytic process to hydrogen evolution, $4 \mathrm{~h}$ bulk electrolysis experiments of $\mathrm{CF}_{3} \mathrm{CO}_{2} \mathrm{H}$ in $\mathrm{MeCN}$ were carried out on a glassy carbon electrode at $-1.60 \mathrm{~V}$ versus $\mathrm{Fc} / \mathrm{Fc}^{+}$in the presence of catalytic amounts of 1 and $[1 \mathrm{H}]\left[\mathrm{BF}_{4}\right]$, respectively. Hydrogen evolution was monitored by GC analysis. From the amount of the electric charge flowed through the electrode, for $\mathbf{1}$ an average turnover frequency (TOF) of $5 \mathrm{~h}^{-1}$ and an overage turnover number (TON) of 20 were calculated as described in the Supporting Information. For $[1 \mathrm{H}]\left[\mathrm{BF}_{4}\right]$, the observed TOF is $8 \mathrm{~h}^{-1}$ and the TON is 32 . Traces of $\mathrm{CO}$ gas as a product of decomposition were detected by $\mathrm{GC}$ in both experiments.

DFT calculations. Both the diamagnetism and the unusually short $\mathrm{Ni}-\mathrm{Fe}$ bond length $(2.426 \AA)$ found for 1 show a striking resemblance to the dinuclear complex [(dppe) Ni(pdt) $\left.\mathrm{Fe}(\mathrm{CO})_{3}\right]$ (2) (Scheme S1, Supporting Information). The diamagnetism of the latter has been linked to the formation of a $\sigma$-bond between $\mathrm{Ni}(\mathrm{I})$ and $\mathrm{Fe}(\mathrm{I})$ that involves a $\mathrm{d}_{z 2}$ orbital on each metal center. ${ }^{23}$

Density functional theory has been used in order to explore the nature of the bonding in $\mathbf{1}$ in more detail. The most stable structure (Figure S13 left, Supporting Information) was found to be a closed-shell singlet state $(S=0)$ with optimized structural parameters fully consistent with those obtained crystallographically (Table S2, Supporting Information) and deviations that are well within the error expected for the chosen method. The structural features of the coordination sphere around the metal centers are well reproduced, with the calculated $\mathrm{Ni}-\mathrm{Fe}$ bond distance being close to the experimental value $(2.437$ vs $2.426 \AA)$.

The triplet state $(S=1)$ was found to be considerably higher in energy (13 kcal mol ${ }^{-1}$, B3LYP/def2-TZVP) compared to the closed-shell singlet. Not surprisingly, higher spin states were even more energetically disfavored. Furthermore, the brokensymmetry singlet state $\left(M_{s}=0\right)$ was analyzed. A detailed analysis of the electronic structure of $\mathbf{1}$ is described in the Supporting Information. Based on the fact that the diradical state is energetically unfavorable, combined with the excellent match between optimized and experimental bond metric data in the closed-shell singlet ground state, we are confident to rule out an open-shell diradical electronic structure of the ground state, consistent with all experimental data presented above.

A localized orbital analysis provides a convenient tool to investigate the bonding situation in the ground state structure of 1 . In analogy to complex 2 , the localization procedure yields three doubly occupied MOs centered on $\mathrm{Fe}(\sim 80 \%)$ with dominant $3 \mathrm{~d}$ character corresponding to a $\left(t_{2 g}\right)^{6}$ configuration in ideal local $O_{\mathrm{h}}$ symmetry, with strong backbonding toward the CO ligands (Table S5, Supporting Information). Likewise, four doubly occupied MOs with 3d character are strongly localized $(>90 \%)$ on the Ni center. In addition, we find one bonding $\mathrm{MO}$ that is delocalized over the two metal centers (44\% Fe, $29 \% \mathrm{Ni}$ ) and the bridging carbon atom $(20 \% \mathrm{C})$. Its occupation number also is 2 , and hence, this interaction can be regarded as a threecenter-two-electron (3c-2e) bond formally involving $\mathrm{Ni}(\mathrm{I}), \mathrm{C} 21$ and $\mathrm{Fe}(\mathrm{I})$ centers.

Turning to the protonated species $[1 \mathrm{H}]^{+}$, different sulfurprotonated isomers have been explored (Figure S14) in order to further support the experimental assignment that the proton is bound to $\mathrm{S} 1$ of the terminal thiolate group. As stated by others, ${ }^{36,37}$ this terminal sulfur atom should be most basic compared to the remaining sulfur-functional groups in the complex, two of which are thioethers and one is a thiolate in a bridging position. The calculations are fully consistent with this suggestion, most evidently seen from the marked energetic preference $\left(>20 \mathrm{kcal} \mathrm{mol}^{-1}\right.$ ) of the $\mathrm{S} 1-\mathrm{H}$ isomer over the other isomers. ${ }^{63}$ Inclusion of the counteranion $\left[\mathrm{BF}_{4}\right]^{-}$adds further stabilization of the $\mathrm{S} 1-\mathrm{H}$ geometry, due to formation of hydrogen bonds. The higher basicity of $S 1$ is also reflected by the more negative charge on this sulfur atom in the unprotonated compound 1 , with a Mulliken atomic charge of -0.282 compared to $0.062,0.086$, and -0.024 for S4, S13, and $\mathrm{S} 16$, respectively. The structural changes induced by protonation of 1 to form $[1 \mathrm{H}]^{+}$are also captured in the optimized geometry of the $\mathrm{S} 1-\mathrm{H}$ isomer. The $\mathrm{Ni}-\mathrm{S} 1$ bond length is elongated by about $0.02 \AA \AA$ in the optimized structure of $[1 \mathrm{H}]^{+}$, which is somewhat less compared to the crystal structure $(0.06$ $\AA) .{ }^{64}$ Finally, the observed increase of the $\mathrm{Fe}-\mathrm{C} 21-\mathrm{O} 22$ angle $\left(158^{\circ}\right.$ in 1 vs $170^{\circ}$ in $\left.[1 \mathrm{H}]^{+}\right)$as well as the $\mathrm{Ni}-\mathrm{C} 21$ bond length $\left(2.01 \AA \AA\right.$ in 1 vs $2.24 \AA$ in $\left.[1 \mathrm{H}]^{+}\right)$upon protonation of $\mathbf{1}$, indicative of a decrease in the bridging character of $\mathrm{CO}$, is also nicely reproduced by the calculations. As a result, the contribution of $\mathrm{C} 21$ to the $3 \mathrm{c}-2 \mathrm{e}$ interaction of the $\mathrm{Fe}-\mathrm{Ni}-$ $\mathrm{C} 21$ core via $\pi$-bonding becomes negligibly small and the resulting localized orbital (Figure 9) approaches the bond situation reported for complex 2 . $^{23}$ The polarity of the $\mathrm{Ni}-\mathrm{Fe}$ bond in $[1 \mathrm{H}]^{+}$is very similar to the one in 2 , with the negative pole on $\mathrm{Ni}$ ( $48 \%$ contribution) and the positive pole on $\mathrm{Fe}$ (33\% contribution). 


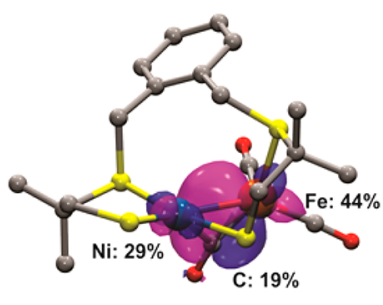

1

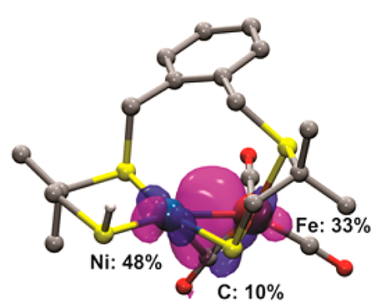

$[1 \mathrm{H}]^{+}$

Figure 9. Localized orbitals (B3LYP/def2-TZVP) displaying the 3c2e-interaction for complex 1 (left) and for $[1 \mathrm{H}]^{+}$(right).

The behavior toward protonation revealed by $\mathbf{1}$ to form $[1 \mathrm{H}]^{+}$is remarkably different from that of 2 (and derivatives thereof), where the coordination sphere does not offer a strong basic center for proton attack. Therefore, protonation of the metal-metal bond is the only viable alternative in this type of complex (Scheme S1, Supporting Information). ${ }^{26,27}$

We have also considered this latter possibility, and therefore optimized an alternative structure with a closed-shell singlet ground state $(S=0)$ featuring a hydride bridge between the metal atoms. The optimized structure of this complex, $\left[\mathrm{Ni}(\mathrm{xbsms})(\mu-\mathrm{H})(\mu-\mathrm{S}) \mathrm{Fe}(\mathrm{CO})_{3}\right]^{+}$, is shown in Figure S16 of the Supporting Information. Protonation of the $\mathrm{Ni}-\mathrm{Fe}$ bond forces the two metal ions further apart $(2.51 \AA)$ compared to $\mathbf{1}$, due to formal one-electron oxidation of each metal center. The formerly bridging carbonyl ligand moves into a more terminal position, remaining coordinated to $\mathrm{Fe}$. Both metal atoms reveal coordination geometries characteristic for divalent low-spin ions (i.e., approximately octahedral and square-planar for lowspin $\mathrm{Fe}(\mathrm{II})$ and $\mathrm{Ni}(\mathrm{II})$, respectively). The hydride bridges both metal ions, and serves as an equatorial ligand in both coordination units. Importantly, this structure lies energetically above $\left(\sim 5 \mathrm{kcal} \mathrm{mol}^{-1}\right)$ the most stable $\mathrm{S} 1-\mathrm{H}$ isomer, further corroborating the higher basicity of the S1 thiolate sulfur atom. The ligand environment in $\mathbf{1}$ may also impose some shielding on the $\mathrm{Ni}-\mathrm{Fe}$ bond, therefore, somewhat hindering protonation. However, the energetic separation is not large, and hence, a $\mathrm{Fe}(\mu-\mathrm{H}) \mathrm{Ni}$ intermediate species should be accessible during the electrocatalytic cycle.

\section{DISCUSSION}

Our results classify 1 and $[1 \mathrm{H}]\left[\mathrm{BF}_{4}\right]$ as low molecular weight mimics of the active site of $[\mathrm{NiFe}]$-hydrogenases with respect to certain structural features and with respect to functionality for electrocatalytic proton reduction. The coordination environment of the metal centers is partly reproduced in the reported model compounds: the nickel center is coordinated by three sulfur atoms and one thiolate is bridging between nickel and iron. Most importantly, the thiol group in $[1 \mathrm{H}]\left[\mathrm{BF}_{4}\right]$ mimics proposed catalytic intermediates of [ $\mathrm{NiFe}]$-hydrogenases with a Cys-SH bond, which have been proposed theoretically but not yet confirmed experimentally. ${ }^{29,36-40}$ One difference between $\mathbf{1}$ and the active site of the [NiFe]hydrogenases is the bridging $\mathrm{CO}$ ligand in the former, which becomes significantly less bridging after protonation and is mainly coordinated to $\mathrm{Fe}$ in $[1 \mathrm{H}]\left[\mathrm{BF}_{4}\right]$. Interestingly, this structural feature resembles the active site of the $[\mathrm{FeFe}]$ hydrogenases, where a similar dichotomy of the binding mode is observed for the bridging $\mathrm{CO} .^{65,66}$

The here reported model compounds reproduce the short $\mathrm{Ni}-\mathrm{Fe}$ distance $(2.43 \AA)$, which is observed in the reduced

forms of the enzyme $(2.5-2.6 \AA)$ compared to the more oxidized states $(2.9 \AA) .{ }^{8,67,68}$ The DFT analysis of the electronic structure of 1 and $[1 \mathrm{H}]\left[\mathrm{BF}_{4}\right]$ is in line with the short bond length and the diamagnetism of these compounds corroborates the presence of a Ni-Fe $\sigma$-bond so that the metal valences are formally assigned as $\mathrm{Ni}(\mathrm{I})$ and $\mathrm{Fe}(\mathrm{I})$. The formal low-spin $\mathrm{Fe}(\mathrm{I})$ state assigned for 1 and $[1 \mathrm{H}]\left[\mathrm{BF}_{4}\right]$ deviates from the low-spin $\mathrm{Fe}(\mathrm{II})$ state postulated for $[\mathrm{NiFe}]$-hydrogenases but is observed for the active site of $[\mathrm{FeFe}]$ hydrogenases. ${ }^{7,8,65}$

The model compound [(dppe $\left.) \mathrm{Ni}(\mathrm{pdt}) \mathrm{Fe}(\mathrm{CO})_{3}\right]$ (2) (Scheme S1), which has been synthesized and characterized by Schröder and co-workers, displays similar electronic properties and is supposed to be an intermediate in the catalytic cycle for proton reduction as shown by Rauchfuss et al. ${ }^{69}$ The metal-metal bond in 2 can be protonated and the resulting bridging hydride $\left[(\mathrm{dppe}) \mathrm{Ni}(\mathrm{pdt})(\mu-\mathrm{H}) \mathrm{Fe}(\mathrm{CO})_{3}\right]$ $[2 \mathrm{H}]\left[\mathrm{BF}_{4}\right]$ (Scheme S1) was shown to be electrocatalytically active. $^{26,27}$ We assume, therefore, that the metal-metal bond might also participate in the catalytic cycle of the proton reduction observed for compounds 1 and $[1 \mathrm{H}]\left[\mathrm{BF}_{4}\right]$. However, all attempts to isolate a $[\mathrm{Ni}(\mu-\mathrm{H}) \mathrm{Fe}]$-species have failed so far. The possibility of a $[\mathrm{NiFe}]$-bond relevant for the catalytic process is also considered for the native system. ${ }^{48}$ Possible intermediates of the catalytic reversible dihydrogen activation by $[\mathrm{NiFe}]$-hydrogenases were investigated in extensive DFT studies and heterolytic cleavage of dihydrogen into a hydride, stabilized in the bridge between the metals, and a proton, stabilized on a terminal sulfur atom, was proposed. ${ }^{34,36,70}$ Intermediates containing a protonated terminal sulfur within the protein are hard to prove experimentally and only indirect experimental evidence is reported in the literature so far. ${ }^{39,40}$ The synthesis of small molecule model compounds is therefore a useful tool to probe the possibility of proposed intermediates from theoretical investigations.

The detailed spectroscopic investigation of 1 and $[1 \mathrm{H}]\left[\mathrm{BF}_{4}\right]$, supported by DFT calculations, illustrates impressively the electronic communication between nickel and iron in these dinuclear compounds. As revealed by FTIR-, absorption, resonance Raman and Mössbauer spectroscopy, a significant change of the electronic structure takes place upon protonation. The iron atom is involved in this change although the protonation takes place at the sulfur atom coordinated to nickel. It is reasonable to assume that this communication takes place via the $\mathrm{Ni}-\mathrm{Fe} \sigma$-bond which was identified by detailed DFT analysis. Both the experimental and the theoretical results highlight the impact of the $\mu$-CO ligand on the electronic changes induced by the protonation of the thiolate.

These results accentuate the importance of the $\{\mathrm{Fe}$ $\left.(\mathrm{CN})_{2}(\mathrm{CO})\right\}$-moiety in the active site of the [NiFe]-hydrogenases. The finely tuned electronic impact of the strong-field ligands $\mathrm{CO}\left(\pi\right.$-backbonding) and $\mathrm{CN}^{-}$( $\sigma$-donating) at iron allows to partly compensate the electronic changes on nickel via electronic interaction between the metals.

The electrochemical experiments show that both $\mathbf{1}$ and $[1 \mathrm{H}]\left[\mathrm{BF}_{4}\right]$ are suitable catalysts for electrocatalytic proton reduction at overpotentials in the range observed for other catalytically active dinuclear [NiFe]-model compounds (300$700 \mathrm{mV}) .^{2,27,28,69}$ The observed turnover number and turnover frequencies are low as well as the stability of the catalysts. As was highlighted by DuBois et al., the incorporation of pendant bases in the coordination sphere of molecular catalysts has a critical effect on their catalytic activity. ${ }^{71-73}$ The basic terminal 
sulfur in compound $\mathbf{1}$ might display this role in the catalytic cycle, promoting the transfer of incoming protons to the metal centers where the electron transfer occurs. Therefore, compound $\mathbf{1}$ is able to provide pathways for both-the acid/ base-reactivity and the redox-activity needed for catalysis. Compound 1 is not protonated by $\mathrm{CF}_{3} \mathrm{CO}_{2} \mathrm{H}\left(\mathrm{p} K_{\mathrm{a}}^{\mathrm{MeCN}}=\right.$ $12.65)^{62}$ and the strong acid $\mathrm{HBF}_{4} \cdot \mathrm{OEt}_{2}\left(\mathrm{pK}_{\mathrm{a}}=-10.3\right.$ in 1,2dichloroethane $)^{74}$ is needed to isolate the protonated species $[1 \mathrm{H}]^{+}$. Therefore, the protonated species can be excluded as a catalytic intermediate. Further experiments are needed for trapping intermediates of the catalytic cycle to provide information about the mechanism and are the aim of ongoing work.

\section{CONCLUSION}

The reported results indicate that both 1 and $[1 \mathrm{H}]\left[\mathrm{BF}_{4}\right]$ are functional and structural mimics of the $[\mathrm{NiFe}]$-hydrogenases. To the best of our knowledge, the protonated complex $[1 \mathrm{H}]\left[\mathrm{BF}_{4}\right]$ is the first dinuclear $[\mathrm{NiFe}]$-model compound mimicking the postulated catalytic intermediates of $[\mathrm{NiFe}]$ hydrogenases with a $\mathrm{Cys}-\mathrm{SH}$ protonation. The electronic interaction between the nickel and iron is conclusively shown by the direct comparison of experimental data and the DFT results obtained for 1 and $[1 \mathrm{H}]]\left[\mathrm{BF}_{4}\right]$. Some features also resemble the active site of the $[\mathrm{FeFe}]$-hydrogenases: (1) the dichotomy of bridging versus the (almost) terminal CO ligation at iron, and (2) the formal $\mathrm{Fe}(\mathrm{I})$ oxidation state which is not observed in the active site of [NiFe]-hydrogenases. The use of elements of basic design principles from both of Nature's best catalysts for hydrogen production in functional model compounds is promising. The communication between the metals facilitates the electron transfer processes throughout the catalytic cycle. Further modifications of the nickel coordination sphere are likely to improve the catalytic performance and the stability of the catalyst. By tuning the electronic structure of the catalyst, the thermodynamic properties of the reaction intermediates may be fine-tuned and the activity of the catalyst toward electrochemical proton reduction may be optimized. Furthermore, mechanistic studies supported by DFT might shed light on the catalytic process and help to better understand the structural and electronic requirements for more active and more stable catalysts.

\section{EXPERIMENTAL SECTION}

Materials. All reactions were carried out under an inert atmosphere of argon using standard Schlenk-techniques or a dry argon glovebox (MBraun LabMaster130). The solvents used for chemical reactions were purified by the solvent purification system MBraun MB SPS-800 Auto. $\mathrm{CD}_{2} \mathrm{Cl}_{2}$ used for NMR-spectroscopy was deoxygenated by three freeze-pump-thaw cycles and stored over molecular sieves in the glovebox. [Ni(xbsms)] and $\left[\mathrm{Fe}(\mathrm{CO})_{3}(\mathrm{BDA})\right]$ were synthesized according to the literature procedures. ${ }^{49,50}$ The supporting electrolyte $\mathrm{NBu}_{4} \mathrm{PF}_{6}$ used for electrochemistry was purchased from Sigma-Aldrich and dried overnight at $100{ }^{\circ} \mathrm{C}$ under vacuum before use. Dichloromethane and acetonitrile used for electrochemistry were HPLC-grade and stabilizer-free, dried over $\mathrm{CaH}_{2}$ and distilled under argon.

Elemental analysis was performed on an Elementar Vario $\mathrm{CHN}$ analyzer.

Spectroscopy. FTIR-spectra were recorded at room temperature on a Perkin-Elmer 2000 NIR FT-Raman spectrometer. For measurements in solution a $\mathrm{KBr}$-cell with a $0.5 \mathrm{~mm}$ pathway was used. Measurements in solid state were carried out in $\mathrm{KBr}$ pellets $(3 \mathrm{mg}$ sample in $300 \mathrm{mg} \mathrm{KBr}$ ).

NMR-spectra were recorded at room temperature using a Bruker DRX 400 spectrometer operating at $400.13 \mathrm{MHz}$ for ${ }^{1} \mathrm{H}$ and 100.61
$\mathrm{MHz}$ for ${ }^{13} \mathrm{C}$. Solvent peaks are used as internal references relative to $\mathrm{Me}_{4} \mathrm{Si}$ for ${ }^{1} \mathrm{H}$ and ${ }^{13} \mathrm{C}$ chemical shifts (listed in ppm). NMR-samples were prepared in the glovebox using J. Young NMR tubes.

Absorption spectra were obtained using a diode-array UV-vis spectrometer (HP 8453). Absorption spectra of samples prepared in an anaerobic chamber were measured in $1 \mathrm{~cm}$ path length cuvettes sealed with a silicon stopper to retain anaerobic conditions, and spectra were measured quickly $(<2 \mathrm{~min}$.) after removing from the anaerobic chamber to avoid decomposition. No changes in the absorption spectra were observed over the time scale of these measurements. Averages of 3 dilutions were considered to obtain accurate extinction coefficients considering only points within the linear range of the instrument (0.005-1 AU).

Resonance Raman spectra were obtained using the $514.5 \mathrm{~nm}$ excitation line from a $\mathrm{Kr}^{+} / \mathrm{Ar}^{+}$ion laser (Spectra Physics BeamLok 20606 S) as described previously. ${ }^{54}$ The sample was contained in a quartz EPR tube within an EPR quartz finger dewar and cooled using liquid nitrogen. Power at the sample was $\sim 50 \mathrm{~mW}$. Spectra were collected for $\sim 4-5$ cycles of $30 \mathrm{~min}$ each for a given wavelength and spectral window; corresponding spectral windows were stitched together. Because of the absence of peaks in the midfrequency range, normalization of the two spectral windows was not possible, so the relative intensities of the high-frequency peaks cannot be compared to the relative intensities of the low-frequency bands. Raman shifts were calibrated to an accuracy of $1 \mathrm{~cm}^{-1}$ using $\mathrm{Na}_{2} \mathrm{SO}_{4}$ and $\mathrm{CCl}_{4}$ for the low-frequency spectral region and acetone and acetonitrile for the high-frequency spectral region. ${ }^{75,76}$

Mössbauer spectra were recorded on a conventional spectrometer with alternating constant acceleration of the $\gamma$-source. The minimum experimental line width was $0.24 \mathrm{~mm} / \mathrm{s}$ (full width at half-height). The sample temperature was maintained constant in an Oxford Instruments Variox or in an Oxford Instruments Mössbauer-Spectromag cryostat with split-pair magnet system; the latter was used for measurements with applied field with the field at the sample being oriented perpendicular to the $\gamma$-beam. The $\gamma$-source $\left({ }^{57} \mathrm{Co} / \mathrm{Rh}, 1.8\right.$ $\mathrm{GBq})$ was kept at room temperature. By using a re-entrant bore tube the $\gamma$-source could be positioned inside the gap of the magnet coils at a position with zero field. Isomer shifts are quoted relative to iron metal at $300 \mathrm{~K}$. Mössbauer spectra at zero field were collected for powder samples (ca. $50 \mathrm{mg}$ ) at $80 \mathrm{~K}$. The Mössbauer spectra recorded at zero field were fitted using the program MFIT (by E.B.) with Lorentzian doublets. Magnetic Mössbauer spectra were simulated with the program MX (by E.B.).

Electrochemistry. All electrochemical measurements were carried out under argon atmosphere at room temperature using an EG\&G PAR 273A instrument. All solutions contained the supporting electrolyte $\mathrm{NBu}_{4} \mathrm{PF}_{6}(0.2 \mathrm{M}$ in dichloromethane or acetonitrile). For cyclic voltammetry, a standard three-electrode configuration was used consisting of a glassy carbon $(d=2 \mathrm{~mm})$ working and counterelectrodes and a $\mathrm{Ag}$-wire placed in a $\mathrm{AgNO}_{3}(0.01 \mathrm{M}$ in $\mathrm{MeCN}) /$ $\mathrm{NBu}_{4} \mathrm{PF}_{6}(0.2 \mathrm{M}$ in $\mathrm{MeCN})$-solution as a pseudoreference electrode. The system was systematically calibrated against ferrocene after each experiment and all the potentials are therefore given versus the $\mathrm{Fc} / \mathrm{Fc}^{+}$ redox potential. Additions of $\mathrm{CF}_{3} \mathrm{CO}_{2} \mathrm{H}$ were made by syringe as a 2 mol L ${ }^{-1}$ solution in dichloromethane or acetonitrile respectively. After each addition of acid, the cyclic voltammogram was recorded immediately after a few seconds of stirring and once again after additional stirring for approximately two minutes. No significant changes were observed.

For the bulk electrolysis experiments, a glassy carbon stick electrode $\left(d=4.1 \mathrm{~mm}, l=25 \mathrm{~mm}, A \sim 3.4 \mathrm{~cm}^{2}\right)$ was used and the solutions were stirred during the electrolysis experiment to achieve better homogeneity. Electrolysis was performed on solutions of the catalyst $\left(2 \mathrm{mmol} \mathrm{L}^{-1}\right)$ and $\mathrm{CF}_{3} \mathrm{CO}_{2} \mathrm{H}\left(0.1 \mathrm{~mol} \mathrm{~L}^{-1}\right)$ in acetonitrile $(7 \mathrm{~mL})$ at the constant potential of $-1.60 \mathrm{~V}$ versus $\mathrm{Fc} / \mathrm{Fc}^{+}$. A blank experiment with a duration of $1000 \mathrm{~s}$ was performed to make sure that no significant amount of charge is consumed by the system without the catalyst $(<1 \%)$. The evolving gas was identified as hydrogen throughout the whole electrolysis experiment using an Agilent 6890 gaschromatograph equipped with a $30 \mathrm{~m}$ Restek RT-Msieve $5 \AA$ 
column and a thermal conductivity detector (TCD) thermostatted at $200{ }^{\circ} \mathrm{C}$. Argon was used as a carrier gas and the oven was thermostatted at $30{ }^{\circ} \mathrm{C}$. Under these conditions, pure hydrogen has an evolution time of $110 \mathrm{~s}$ and pure $\mathrm{CO}$ gas of $480 \mathrm{~s}$.

Crystal-Structure Analysis. A dark red single crystal of 1-0.5 $\mathrm{Et}_{2} \mathrm{O}$ and a brown crystal of $[1 \mathrm{H}]\left[\mathrm{BF}_{4}\right] \cdot 0.5$ 1,2-difluorobenzene were mounted on a Bruker-AXS Kappa Mach3 APEX-II diffractometer equipped with an Incoatec Helios mirror monochromator (Mo K $\alpha \lambda=$ $0.71073 \AA$ ) and a nitrogen cold stream adjusted to $100 \mathrm{~K}$. Data were integrated and averaged with the program SAINT. ${ }^{77}$ Final cell constants were obtained from least-squares fits of all measured reflections. An empirical absorption correction was performed using the Gaussian procedure embedded in SADABS. ${ }^{78}$ The structures were readily solved by Patterson methods and subsequent difference Fourier techniques. The Siemens ShelXTL software package was used for solution and artwork of the structures; ShelXL97 was used for the refinement. ${ }^{79,80}$ All non-hydrogen atoms were anisotropically refined. Hydrogen atoms bound to carbon were placed at calculated positions and refined as riding atoms with isotropic displacement parameters.

The protonation of a sulfur atom $(\mathrm{S} 1)$ in $[1 \mathrm{H}] \cdot 0.5$ 1,2difluorobenzene could be detected from the difference map. The hydrogen atom position was isotropically refined without geometrical constraints but its thermal displacement parameter was restrained to be 1.2 times the $U_{\text {eq }}$ value of the sulfur atom to which it is bound. Crystal data and structural refinement details are available in the Supporting Information.

Synthesis of $\left[\mathrm{Ni}(\mathrm{xbsms})(\mu-\mathrm{CO})(\mu-\mathrm{S}) \mathrm{Fe}(\mathrm{CO})_{2}\left({ }^{\prime} \mathrm{S}^{\prime}\right)\right]$ 1. A solution of $[\mathrm{Ni}(\mathrm{xbsms})]\left(0.28 \mathrm{~g}, 0.70 \mathrm{mmol}, 1.0\right.$ equiv) and $\left[\mathrm{Fe}(\mathrm{CO})_{3}(\mathrm{BDA})\right]$ $\left(0.20 \mathrm{~g}, 0.70 \mathrm{mmol}, 1.0\right.$ equiv) in $\mathrm{CH}_{2} \mathrm{Cl}_{2}(10 \mathrm{~mL})$ was stirred at room temperature. The solution turned red after a couple of minutes. The reaction was monitored by FTIR-spectroscopy, and when the carbonyl absorption bands at 2065, 2005, and $1985 \mathrm{~cm}^{-1}$ assigned to $\left[\mathrm{Fe}(\mathrm{CO})_{3}(\mathrm{BDA})\right]$ had disappeared, the reaction mixture was filtered to remove insoluble precipitate, and the solvent removed under reduced pressure. The residue was subjected to preparative column chromatography separation using $\mathrm{CH}_{2} \mathrm{Cl}_{2} / \mathrm{Et}_{2} \mathrm{O}$ (1:5) as eluent on silica. After the free benzylideneacetone (BDA) was removed in the first fraction, only $\mathrm{CH}_{2} \mathrm{Cl}_{2}$ was used as eluent. The solvent was removed under reduced pressure and the product was isolated as a red microcrystalline solid (0.24 g, $0.44 \mathrm{mmol}, 63 \%) .{ }^{1} \mathrm{H} \mathrm{NMR}(400 \mathrm{MHz}$, $\left.\mathrm{CD}_{2} \mathrm{Cl}_{2}, 300 \mathrm{~K}\right): \delta / \mathrm{ppm}=7.52(\mathrm{~m}, 1 \mathrm{H}, \mathrm{Ar}), 7.37(\mathrm{~m}, 3 \mathrm{H}, \mathrm{Ar}), 4.90$ $\left(\mathrm{d}, 1 \mathrm{H},{ }^{2} \mathrm{~J}=10.7 \mathrm{~Hz}, \mathrm{ArCH}_{2}\right), 4.28\left(\mathrm{~d}, 1 \mathrm{H},{ }^{2} J=10.6 \mathrm{~Hz}, \mathrm{ArCH}_{2}\right), 3.98$ $\left(\mathrm{d}, 1 \mathrm{H},{ }^{2} \mathrm{~J}=11.7 \mathrm{~Hz}, \mathrm{ArCH}_{2}\right.$ ), $3.81\left(\mathrm{~d}, 1 \mathrm{H},{ }^{2} \mathrm{~J}=11.3 \mathrm{~Hz}, \mathrm{ArCH}_{2}\right), 2.96$ $\left(\mathrm{s}, 2 \mathrm{H}, \mathrm{CH}_{2}\right), 2.78\left(\mathrm{~d}, 1 \mathrm{H},{ }^{2} \mathrm{~J}=13.2 \mathrm{~Hz}, \mathrm{CH}_{2}\right), 2.50\left(\mathrm{~d}, 1 \mathrm{H},{ }^{2} \mathrm{~J}=13.2\right.$ $\mathrm{Hz}, \mathrm{CH}_{2}$ ), $1.82-1.80$ (ss, $\left.6 \mathrm{H}, \mathrm{CH}_{3}\right), 1.65\left(\mathrm{~s}, 3 \mathrm{H}, \mathrm{CH}_{3}\right), 1.45(\mathrm{~s}, 3 \mathrm{H}$, $\left.\mathrm{CH}_{3}\right) \cdot{ }^{13} \mathrm{C}\left\{{ }^{1} \mathrm{H}\right\}$-NMR $\left(100 \mathrm{MHz}, \mathrm{CD}_{2} \mathrm{Cl}_{2}, 300 \mathrm{~K}\right): \delta / \mathrm{ppm}=217.7$ (CO), 134.4 (Ar, C $\mathrm{C}_{\mathrm{q}}$ ), 133.7 (Ar, $\mathrm{C}_{\mathrm{q}}$ ), 132.9 (Ar), $131.4(\mathrm{Ar}), 129.3$ (Ar), $129.2(\mathrm{Ar}), 67.1\left(\mathrm{ArCH}_{2}\right), 62.2\left(\mathrm{ArCH}_{2}\right), 48.5\left(\mathrm{CH}_{2}\right), 40.7$

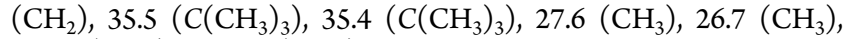
$25.7\left(\mathrm{CH}_{3}\right), 25.6\left(\mathrm{CH}_{3}\right)$. Elemental analysis calculated for $\mathrm{C}_{19} \mathrm{H}_{24} \mathrm{FeNiO}_{3} \mathrm{~S}_{4}$ : C 42.01, H 4.45. Found: $\mathrm{C} 42.45, \mathrm{H} 3.82 .{ }^{57} \mathrm{Fe}-$ Mössbauer $(4.2 \mathrm{~K}, 4.0 \mathrm{~T}): \delta=0.06 \mathrm{~mm} / \mathrm{s}, \Delta E_{\mathrm{O}}=1.39 \mathrm{~mm} / \mathrm{s}, \eta=$ 0.92. $\operatorname{FTIR}\left(\mathrm{CH}_{2} \mathrm{Cl}_{2}\right): 2012$ (s, CO), 1954 (s, CO), 1854 (m, br, CO) $\mathrm{cm}^{-1}$. X-ray suitable crystals of $\mathbf{1} \cdot 0.5 \mathrm{Et}_{2} \mathrm{O}$ were grown by the overlaying technique from dichloromethane and diethylether at $-40^{\circ}$.

Synthesis of $\left[\left({ }^{\prime} \mathrm{S}^{\prime} \mathrm{H}\right) \mathrm{Ni}(\mathrm{xbsms})(\mu-\mathrm{CO})(\mu-\mathrm{S}) \mathrm{Fe}(\mathrm{CO})_{2}\left({ }^{\prime} \mathrm{S}^{\prime}\right)\right]\left[\mathrm{BF}_{4}\right]$ [1H] $\left[\mathrm{BF}_{4}\right]$. A solution of $1\left(54 \mathrm{mg}, 0.10 \mathrm{mmol}, 1.0\right.$ equiv) in $\mathrm{CH}_{2} \mathrm{Cl}_{2}$ $(7 \mathrm{~mL})$ was treated with $\mathrm{HBF}_{4} \cdot \mathrm{OEt}_{2}(14 \mu \mathrm{L}, 0.10 \mathrm{mmol}, 1.0$ equiv $)$ at room temperature. The solution turned immediately from red to brown. It was overlaid with $n$-pentane $(7 \mathrm{~mL})$ and stored for $12 \mathrm{~h}$ at $-35^{\circ} \mathrm{C}$. Dark-brown microcrystals of $[1 \mathrm{H}]\left[\mathrm{BF}_{4}\right](67 \mathrm{mg}, 0.094 \mathrm{mmol}$, 94\%) were isolated after filtration and dried under vacuum. Both the ${ }^{1} \mathrm{H}$ NMR spectrum and the elemental analysis reveal that one solvate molecule of dichloromethane per molecule of $[1 \mathrm{H}]\left[\mathrm{BF}_{4}\right]$ has to be taken into account so that the molecular mass to be used is $715.93 \mathrm{~g} /$ mol. ${ }^{1} \mathrm{H}$ NMR (400 MHz, $\left.\mathrm{CD}_{2} \mathrm{Cl}_{2}, 300 \mathrm{~K}\right): \delta / \mathrm{ppm}=7.40(\mathrm{~m}, 4 \mathrm{H}$, $\mathrm{Ar}), 4.94\left(\mathrm{~d}, 1 \mathrm{H},{ }^{2} \mathrm{~J}=11.6 \mathrm{~Hz}, \mathrm{ArCH}_{2}\right), 4.79(\mathrm{~s}, 1 \mathrm{H}, \mathrm{SH}), 4.71(\mathrm{~d}, 1 \mathrm{H}$, $\left.{ }^{2} J=11.8 \mathrm{~Hz}, \mathrm{ArCH}_{2}\right), 4.49\left(\mathrm{~d}, 1 \mathrm{H},{ }^{2} J=11.6 \mathrm{~Hz}, \mathrm{ArCH}_{2}\right), 3.80(\mathrm{~d}, 1 \mathrm{H}$, $\left.{ }^{2} J=11.8 \mathrm{~Hz}, \mathrm{ArCH}_{2}\right), 3.23\left(\mathrm{~d}, 1 \mathrm{H},{ }^{2} J=12.7 \mathrm{~Hz}, \mathrm{CH}_{2}\right), 3.00(\mathrm{~m}, 2 \mathrm{H}$, $\left.\mathrm{CH}_{2}\right), 2.86\left(\mathrm{~d}, 1 \mathrm{H},{ }^{2} \mathrm{~J}=12.8 \mathrm{~Hz}, \mathrm{CH}_{2}\right), 1.92-1.89\left(\mathrm{ss}, 6 \mathrm{H}, \mathrm{CH}_{3}\right), 1.48$ (s, 3H, $\left.\mathrm{CH}_{3}\right), 1.42\left(\mathrm{~s}, 3 \mathrm{H}, \mathrm{CH}_{3}\right) \cdot{ }^{13} \mathrm{C}\left\{{ }^{1} \mathrm{H}\right\}-\mathrm{NMR}\left(100 \mathrm{MHz}, \mathrm{CD}_{2} \mathrm{Cl}_{2}\right.$, $300 \mathrm{~K}): \delta / \mathrm{ppm}=208.1(\mathrm{CO}), 133.9\left(\mathrm{Ar}, \mathrm{C}_{\mathrm{q}}\right), 133.3(\mathrm{Ar}), 133.1(\mathrm{Ar}$, $\left.\mathrm{C}_{\mathrm{q}}\right), 131.8(\mathrm{Ar}), 130.0(\mathrm{Ar}), 129.8(\mathrm{Ar}), 63.1\left(\mathrm{ArCH}_{2}\right), 59.9\left(\mathrm{ArCH}_{2}\right)$, $45.8\left(\mathrm{CH}_{2}\right), 39.4\left(\mathrm{CH}_{2}\right), 37.6\left(\mathrm{C}\left(\mathrm{CH}_{3}\right)_{3}\right), 33.0\left(\mathrm{C}\left(\mathrm{CH}_{3}\right)_{3}\right), 27.4$ $\left(\mathrm{CH}_{3}\right), 26.6\left(\mathrm{CH}_{3}\right), 25.0\left(\mathrm{CH}_{3}\right), 24.9\left(\mathrm{CH}_{3}\right)$. Elemental analysis calculated for $\mathrm{C}_{20} \mathrm{H}_{27} \mathrm{BCl}_{2} \mathrm{~F}_{4} \mathrm{FeNiO}_{3} \mathrm{~S}_{4}$ (one solvate molecule of $\mathrm{CH}_{2} \mathrm{Cl}_{2}$ included): $\mathrm{C} 33.55, \mathrm{H}$ 3.80. Found: $\mathrm{C} 33.92, \mathrm{H} 3.87 .{ }^{57} \mathrm{Fe}-$ Mössbauer $(4.2 \mathrm{~K}, 4.0 \mathrm{~T}): \delta=0.05 \mathrm{~mm} / \mathrm{s}, \Delta E_{\mathrm{Q}}=-1.20 \mathrm{~mm} / \mathrm{s}, \eta=$ 0.20. FTIR(KBr): 2512 (m, br, SH), 2034 (s, CO), 1982 (s, CO), 1932 (s, CO). X-ray suitable crystals of $[1 \mathrm{H}]\left[\mathrm{BF}_{4}\right] \cdot 0.51,2-$ difluorobenzene were grown by the vapor diffusion method from 1,2-difluorobenzene and $n$-pentane at $-40^{\circ}$.

Computational Methods. All electronic structure calculations presented in this paper were carried out using the ORCA program package. ${ }^{81}$ Scalar relativistic effects were incorporated by the allelectron zeroth-order regular approximation (ZORA). ${ }^{82,83}$ Unconstrained geometry optimizations and frequency calculations of the model complexes were carried out at DFT level, using the BP86 GGA functional in conjunction with the RI-J approximation. ${ }^{84-89}$ Initial atomic coordinates were taken from single-crystal X-ray diffraction experiments. The recontracted scalar-relativistic def2-TZVP basis set was used on all atoms, combined with the corresponding def2-TZVP/J auxiliary basis. ${ }^{90-93}$ Dispersion effects were accounted for by the use of Grimme's most recent empirical van der Waals correction (VDW10).$^{94}$ Stationary points were confirmed to be minima by the absence of imaginary frequencies. Final single point energies were computed using the B3LYP hybrid functional in conjunction with the def2-TZVP basis set. ${ }^{95-97}$ The electronic structure was analyzed by means of localized molecular orbitals using the Pipek-Mezey population-localization scheme. ${ }^{98}$ Details for the computation of the Mössbauer parameters are given in the Supporting Information.

\section{ASSOCIATED CONTENT}

\section{Supporting Information}

Details on spectroscopic, electrochemical and computational investigation as well as crystallographic data. This material is available free of charge via the Internet at http://pubs.acs.org.

\section{AUTHOR INFORMATION}

\section{Corresponding Author}

wolfgang.lubitz@cec.mpg.de

Notes

The authors declare no competing financial interest.

\section{ACKNOWLEDGMENTS}

This work was supported by the Max Planck Society. We also thank the Fonds der Chemischen Industrie for the Doctoral Kekule Fellowship (K.W.) and the Alexander von Humboldt Foundation for the AvH Postdoctoral Research Fellowship (H.S.S.).

\section{REFERENCES}

(1) Crabtree, G. W.; Dresselhaus, M. S. MRS Bull. 2008, 33, 421.

(2) Wang, M.; Chen, L.; Sun, L. Energy Environ. Sci. 2012, 5, 6763.

(3) Alper, J. Science 2003, 299, 1686.

(4) Vignais, P. M.; Billoud, B. Chem. Rev. 2007, 107, 4206.

(5) Volbeda, A.; Charon, M. H.; Piras, C.; Hatchikian, E. C.; Frey, M.; Fontecilla-Camps, J. C. Nature 1995, 373, 580.

(6) Fontecilla-Camps, J. C.; Volbeda, A.; Cavazza, C.; Nicolet, Y. Chem. Rev. 2007, 107, 4273.

(7) Lubitz, W.; Reijerse, E.; van Gastel, M. Chem. Rev. 2007, 107, 4331.

(8) Ogata, H.; Lubitz, W.; Higuchi, Y. Dalton Trans. 2009, 7577.

(9) Canaguier, S.; Artero, V.; Fontecave, M. Dalton Trans. 2008, 315.

(10) Tard, C.; Pickett, C. J. Chem. Rev. 2009, 109, 2245.

(11) Ohki, Y.; Tatsumi, K. Eur. J. Inorg. Chem. 2011, 2011, 973.

(12) van der Vlucht, J. I.; Meyer, F. Met. Ions Life Sci. 2007, 2, 181. 
(13) Li, Z.; Ohki, Y.; Tatsumi, K. J. Am. Chem. Soc. 2005, 127, 8950.

(14) Tanino, S.; Li, Z.; Ohki, Y.; Tatsumi, K. Inorg. Chem. 2009, 48, 2358

(15) Jiang, J.; Maruani, M.; Solaimanzadeh, J.; Lo, W.; Koch, S. A.; Millar, M. Inorg. Chem. 2009, 48, 6359.

(16) Ohki, Y.; Yasumura, K.; Kuge, K.; Tanino, S.; Ando, M.; Li, Z.; Tatsumi, K. Proc. Nalt. Acad. Sci. U.S.A. 2008, 105, 7652.

(17) Lai, C. H.; Reibenspies, J. H.; Darensbourg, M. Y. Angew. Chem., Int. Ed. 1996, 35, 2390.

(18) Osterloh, F.; Saak, W.; Haase, D.; Pohl, S. Chem. Commun. 1997, 979.

(19) Davies, C.; Evans, J.; Hughes, L.; Longhurst, S.; Sanders, J. R. Chem. Commun. 1999, 1935.

(20) Liaw, W. F.; Chiang, C. Y.; Lee, G. H.; Peng, S. M.; Lai, C. H.; Darensbourg, M. Y. Inorg. Chem. 2000, 39, 480.

(21) Sellmann, D.; Geipel, F.; Lauderbach, F.; Heinemann, F. W. Angew. Chem., Int. Ed. 2002, 41, 632.

(22) Verhagen, J. A.; Lutz, M.; Spek, A. L.; Bouwman, E. Eur. J. Inorg. Chem. 2003, 2003, 3968.

(23) Zhu, W.; Marr, A. C.; Wang, Q.; Neese, F.; Spencer, D. J. E.; Blake, A. J.; Cooke, P. A.; Wilson, C.; Schröder, M. Proc. Natl. Acad. Sci. U.S.A. 2005, 102, 18280.

(24) Stenson, P. A.; Marin-Becerra, A.; Wilson, C.; Blake, A. J.; McMaster, J.; Schröder, M. Chem. Commun. 2006, 317.

(25) Hsieh, C. H.; Chupik, R. B.; Brothers, S. M.; Hall, M. B.; Darensbourg, M. Y. Dalton Trans. 2011, 40, 6047.

(26) Barton, B. E.; Whaley, C. M.; Rauchfuss, T. B.; Gray, D. L. J. Am. Chem. Soc. 2009, 131, 6942.

(27) Barton, B. E.; Rauchfuss, T. B. J. Am. Chem. Soc. 2010, 132, 14877.

(28) Canaguier, S.; Field, M.; Oudart, Y.; Pecaut, J.; Fontecave, M.; Artero, V. Chem. Commun. 2010, 46, 5876.

(29) De Gioia, L.; Fantucci, P.; Guigliarelli, B.; Bertrand, P. Inorg. Chem. 1999, 38, 2658.

(30) Brecht, M.; van Gastel, M.; Buhrke, T.; Friedrich, B.; Lubitz, W. J. Am. Chem. Soc. 2003, 125, 13075.

(31) Foerster, S.; van Gastel, M.; Brecht, M.; Lubitz, W. J. Biol. Inorg. Chem. 2005, 10, 51.

(32) Pandelia, M. E.; Infossi, P.; Stein, M.; Giudici-Orticoni, M. T.; Lubitz, W. Chem. Commun. 2012, 48, 823.

(33) Stein, M.; van Lenthe, E.; Baerends, E. J.; Lubitz, W. J. Am. Chem. Soc. 2001, 123, 5839.

(34) Stein, M.; Lubitz, W. Phys. Chem. Chem. Phys. 2001, 3, 5115.

(35) Stein, M.; Lubitz, W. Phys. Chem. Chem. Phys. 2001, 3, 2668.

(36) Niu, S.; Thomson, L. M.; Hall, M. B. J. Am. Chem. Soc. 1999, 121, 4000 .

(37) Li, S.; Hall, M. B. Inorg. Chem. 2001, 40, 18.

(38) Dole, F.; Fournel, A.; Magro, V.; Hatchikian, E. C.; Bertrand, P.; Guigliarelli, B. Biochemistry 1997, 36, 7847.

(39) de Lacey, A. L.; Hatchikian, E. C.; Volbeda, A.; Frey, M.; Fontecilla-Camps, J. C.; Fernandez, V. M. J. Am. Chem. Soc. 1997, 119, 7181.

(40) Ogata, H.; Mizoguchi, Y.; Mizuno, N.; Miki, K.; Adachi, S.; Yasuoka, N.; Yagi, T.; Yamauchi, O.; Hirota, S.; Higuchi, Y. J. Am. Chem. Soc. 2002, 124, 11628.

(41) Lee, C. M.; Chen, C. H.; Ke, S. C.; Lee, G. H.; Liaw, W. F. J. Am. Chem. Soc. 2004, 126, 8406.

(42) Lee, C. M.; Chuang, Y. L.; Chiang, C. Y.; Lee, G. H.; Liaw, W. F. Inorg. Chem. 2006, 45, 10895.

(43) Chen, C. H.; Lee, G. H.; Liaw, W. F. Inorg. Chem. 2006, 45, 2307.

(44) Lee, C. M.; Chiou, T. W.; Chen, H. H.; Chiang, C. Y.; Kuo, T. S.; Liaw, W. F. Inorg. Chem. 2007, 46, 8913.

(45) Autissier, V.; Clegg, W.; Harrington, R. W.; Henderson, R. A. Inorg. Chem. 2004, 43, 3098.

(46) Autissier, V.; Zarza, P. M.; Petrou, A.; Henderson, R. A.; Harrington, R. W.; Clegg, W. C. Inorg. Chem. 2004, 43, 3106.

(47) Petrou, A. L.; Koutselos, A. D.; Wahab, H. S.; Clegg, W.; Harrington, R. W.; Henderson, R. A. Inorg. Chem. 2011, 50, 847.
(48) Lindahl, P. A. J. Inorg. Biochem. 2012, 106, 172.

(49) Verhagen, J. A. W.; Ellis, D. D.; Lutz, M.; Spek, A. L.; Bouwman, E. Dalton Trans. 2002, 1275.

(50) Howell, J. A. S.; Johnson, B. F. G.; Josty, P. L.; Lewis, J. J. Organomet. Chem. 1972, 39, 329.

(51) van Gastel, M.; Fichtner, C.; Neese, F.; Lubitz, W. Biochem. Soc. Trans. 2005, 33, 7.

(52) Cotton, F. A.; Wilkinson, G.; Murillo, C. A.; Bochmann, M. Advanced Inorganic Chemistry; Wiley-Interscience: New York, 1999.

(53) Clayden, J.; Greeves, N.; Warren, S.; Wothers, P. Organic Chemistry; Oxford University Press: New York, 2001.

(54) Shafaat, H. S.; Weber, K.; Petrenko, T.; Neese, F.; Lubitz, W. Inorg. Chem. 2012, 51, 11787.

(55) Römelt, M.; Ye, S.; Neese, F. Inorg. Chem. 2008, 48, 784.

(56) Gütlich, P.; Bill, E.; Trautwein, A. X. Mössbauer Spectroscopy and Transition Metal Chemistry. Fundamentals and Applications; Springer: Berlin, 2011.

(57) Surerus, K. K.; Chen, M.; van der Zwaan, J. W.; Rusnak, F. M.; Kolk, M.; Duin, E. C.; Albracht, S. P. J.; Münck, E. Biochemistry 1994, 33, 4980.

(58) Li, B.; Liu, T.; Popescu, C. V.; Bilko, A.; Darensbourg, M. Y. Inorg. Chem. 2009, 48, 11283.

(59) Schilter, D.; Nilges, M. J.; Chakrabarti, M.; Lindahl, P. A.; Rauchfuss, T. B.; Stein, M. Inorg. Chem. 2012, 51, 2338.

(60) Felton, G. A. N.; Glass, R. S.; Lichtenberger, D. L.; Evans, D. H. Inorg. Chem. 2006, 45, 9181.

(61) Fourmond, V.; Jacques, P. A.; Fontecave, M.; Artero, V. Inorg. Chem. 2010, 49, 10338.

(62) Izutsu, K. Acid-Base Dissociation Constants in Dipolar Aprotic Solvents; Blackwell Scientific Publications: Oxford, U.K., 1990.

(63) We have optimized two different structures for the S1-H isomer; in one the proton is pointing upwards and in the other the proton is pointing downwards. There is a marginal energetic preference for the $\mathrm{S} 1-\mathrm{H}_{\text {down }}$ isomer when the counterion is neglected in the calculations, but $\mathrm{S} 1-\mathrm{H}_{\mathrm{up}}$ becomes the preferred isomer once $\left[\mathrm{BF}_{4}\right]^{-}$is present in the optimization.

(64) Inclusion of $\left[\mathrm{BF}_{4}\right]^{-}$increases this value to $\sim 0.04 \AA$.

(65) de Lacey, A. L.; Fernández, V. M.; Rousset, M.; Cammack, R. Chem. Rev. 2007, 107, 4304.

(66) Adamska, A.; Silakov, A.; Lambertz, C.; Rüdiger, O.; Happe, T.; Reijerse, E.; Lubitz, W. Angew. Chem., Int. Ed. 2012, 51, 11458.

(67) Davidson, G.; Choudhury, S. B.; Gu, Z.; Bose, K.; Roseboom, W.; Albracht, S. P. J.; Maroney, M. J. Biochemistry 2000, 39, 7468.

(68) Volbeda, A.; Garcin, E.; Piras, C.; de Lacey, A. L.; Fernandez, V. M.; Hatchikian, E. C.; Frey, M.; Fontecilla-Camps, J. C. J. Am. Chem. Soc. 1996, 118, 12989.

(69) Carroll, M. E.; Barton, B. E.; Gray, D. L.; Mack, A. E.; Rauchfuss, T. B. Inorg. Chem. 2011, 50, 9554.

(70) Bruschi, M.; Zampella, G.; Fantucci, P.; De Gioia, L. Coord. Chem. Rev. 2005, 249, 1620.

(71) Yang, J. Y.; Bullock, R. M.; Rakowski DuBois, M.; DuBois, D. L. MRS Bull. 2011, 36, 39.

(72) O’Hagan, M.; Shaw, W. J.; Raugei, S.; Chen, S.; Yang, J. Y.; Kilgore, U. J.; DuBois, D. L.; Bullock, R. M. J. Am. Chem. Soc. 2011, 133, 14301.

(73) Rakowski DuBois, M.; DuBois, D. L. Chem. Soc. Rev. 2009, 38, 62.

(74) Kütt, A.; Rodima, T.; Saame, J.; Raamat, E.; Mäemets, V.; Kaljurand, I.; Koppel, I. A.; Garlyauskayte, R. Y.; Yagupolskii, Y. L.; Yagupolskii, L. M.; Bernhardt, E.; Willner, H.; Leito, I. J. Org. Chem. 2011, 76, 391.

(75) Ito, M. Spectrochim. Acta 1965, 21, 731.

(76) Ferraro, J. R.; Nakamoto, K. Introductory Raman Spectroscopy; Academic Press, Boston MA, 1994.

(77) SAINT, Vers. 7.46A; Bruker-AXS, Inc.: Madison, WI. 2008.

(78) SADABS, Vers. 2008; Bruker-AXS, Inc: Madison, WI, 2008.

(79) ShelXTL 6.14; Bruker AXS, Inc.: Madison, WI, 2003.

(80) Sheldrick, G. M. ShelXTL97; University of Göttingen: Germany, 1997. 
(81) Neese, F. WIREs Comput. Mol. Sci. 2012, 2, 73.

(82) van Lenthe, E.; Baerends, E. J.; Snijders, J. G. J. Chem. Phys. 1993, 99, 4597.

(83) van Wüllen, C. J. J. Chem. Phys. 1998, 109, 392.

(84) Becke, A. D. Phys. Rev. A 1988, 38, 3098.

(85) Perdew, J. P. Phys. Rev. B 1986, 33, 8822.

(86) Baerends, E. J.; Ellis, D. E.; Ros, P. Chem. Phys. 1973, 2, 41.

(87) Dunlap, B. I.; Connolly, J. W. D.; Sabin, J. R. J. Chem. Phys. 1979, 71, 3396.

(88) Vahtras, O.; Almlöf, J.; Feyereisen, M. W. Chem. Phys. Lett. 1993, 213, 514.

(89) Neese, F. J. Comput. Chem. 2003, 24, 1740.

(90) Pantazis, D. A.; Chen, X. Y.; Landis, C. R.; Neese, F. J. Chem. Theory Comput. 2008, 4, 908.

(91) Weigend, F. Phys. Chem. Chem. Phys. 2006, 8, 1057.

(92) Eichkorn, K.; Treutler, O.; Öhm, H.; Häser, M.; Ahlrichs, R. Chem. Phys. Lett. 1995, 240, 283.

(93) Eichkorn, K.; Weigend, F.; Treutler, O.; Ahlrichs, R. Theor. Chem. Acc. 1997, 97, 119.

(94) Grimme, S.; Antony, J.; Ehrlich, S.; Krieg, H. J. Chem. Phys. 2010, 132, 154104.

(95) Becke, A. D. J. Chem. Phys. 1993, 98, 5648.

(96) Stephens, P. J.; Devlin, F. J.; Chabalowski, C. F.; Frisch, M. J. J. Phys. Chem. 1994, 98, 11623.

(97) Lee, C.; Yang, W.; Parr, R. G. Phys. Rev. B 1988, 37, 785.

(98) Pipek, J.; Mezey, P. G. J. Chem. Phys. 1989, 90, 4916. 